THE AUSTRALIAN NATIONAL UNIVERSITY

WORKING PAPERS IN ECONOMICS AND ECONOMETRICS

\title{
Disagreement in Partners' Reports of Financial Difficulty
}

\author{
Robert Breunig \\ Australian National University \\ Deborah A. Cobb-Clark \\ Australian National University and IZA \\ Xiaodong Gong \\ Australian National University and IZA \\ Daniella Venn \\ Department of Employment and Workplace Relations
}

Working Paper No. 453

May 2005

ISBN: 0868314536

\begin{abstract}
We use unique data in which both partners report about household finances to demonstrate that there is often disagreement about whether the household has experienced financial difficulty in the past year. Four alternative explanations for this disagreement are tested using the data. The results indicate that disagreement may be related to the severity of the underlying material hardship rather than to gender differences, information asymmetries, or individual (as opposed to household) views of financial difficulty. This implies that standard surveys which collect information about the household's financial position from a representative individual may fail to completely characterize the nature of material hardship.
\end{abstract}

Keywords: Household Finances, Survey Methodology, Material Hardship JEL Classification: C42, D14, I31

* Corresponding Author: Deborah Cobb-Clark, SPEAR Centre, RSSS, Australian National University, Canberra ACT 0200 Australia Phone: (612) 6125-3267 , Fax: (612) 6125-0182, E-mail: deborah.cobb-clark@anu.edu.au. The authors would like to thank participants of the Australasian Econometric Society Meetings 2004, seminar participants at the University of Groningen, and Peter Koreman for their comments. 


\section{Introduction}

Moving beyond standard poverty statistics - which reflect low income - to consider the material hardship that stems from a lack of consumption provides a fuller picture of households' overall economic well-being. There is often only a weak relationship between low income and deprivation since family needs are as important as economic resources in understanding which families are at risk of material hardship (see Bauman, 1999a; 1999b; Layte, et al., 2000; Mayer and Jencks, 1988; Whelan, et al., 2001). Consequently, many surveys such as the Survey of Income and Program Participation, the British Household Panel Survey, the U.S. General Social Survey, the German Socio-Economic Panel, and the European Community Household Panel have begun to ask directly about a household's inability to, for example, make rent or mortgage payments, pay for utilities, purchase adequate food or receive medical treatment. In each of these surveys, a single individual (i.e., the reference person, household head, or random individual) is called upon to report incidents of financial difficulty on behalf of the entire household. These individual reports of financial difficulty are then often used to make inferences about consumption poverty or underlying material hardship in the household ${ }^{1}$.

It would appear, however, that family members rarely have the same view of the household's financial situation. Men report higher levels of income and assets than their partners, while women report higher levels of debt (Zargorsky, 2003). Moreover, husbands and wives often disagree on the system they use to organize their household finances (Dobbelsteen and Kooreman, 1997) and the minimum income needed by the family to make ends meet (Plug and van Praag, 1998). Very little is known about how partners see other dimensions of the family's finances, however.

In this paper we investigate partners' views of household financial difficulty using data which to our knowledge is unique in asking both partners separately about the household's inability to pay its bills. ${ }^{2}$ We have three objectives. First, we wish to

\footnotetext{
${ }^{1}$ These surveys often indicate extensive material hardship. For example, Bauman (1999a) finds that in 1995 approximately 49 million people in the United States - about one in five - lived in a household that had at least one difficulty in meeting basic needs.

${ }^{2}$ The National Longitudinal Surveys (NLS) are the only U.S. data sets with financial information collected separately from each partner (see Zagorsky, 2003 for a discussion). However, the NLS does
} 
analyze the extent to which partners disagree about whether or not the household has experienced financial difficulty in the previous year. Secondly, we test alternative explanations for this disagreement. Lastly, we examine whether having two reports of financial difficulty provides any additional information about the family's material hardship relative to studies which use the report of only one individual. Understanding the source of partners' disagreement has important implications for surveys which rely upon a representative agent to report on the household's finances. Our results indicate disagreement is not random, but is closely related to the household's income level, demographic structure, housing status, and the nature of partners' relationship. More specifically, disagreement appears to be related to the severity of material hardship. This implies that surveys which rely upon a representative individual may be misleading about the degree of material hardship experienced by couples by failing to measure some cases of intermediate hardship.

Finally we examine whether cohabiting couples who are not legally married are similar to married couples in their propensity to report financial difficulty and their disagreement about household experiences of financial difficulty. Since many US surveys do not gather data on unmarried couples, this question also has an important bearing on survey design.

\section{Data}

The data come from the second wave of the Household Income and Labour Dynamics in Australia (HILDA) Survey. ${ }^{3}$ The HILDA Survey is a nationally representative panel survey of Australian households. The population frame is all members of private dwellings in Australia with the exception of overseas residents temporarily living in Australia, diplomatic personnel of overseas governments, and members of non-Australian defence forces. The institutionalized are excluded from the frame as are people living in very remote areas. Relative to population estimates, the HILDA sample appears to slightly under-represent residents of Sydney, men, non-English speaking immigrants, and non-married individuals. (See HILDA Survey Annual

not ask directly about incidents of financial difficulty.

${ }^{3}$ See Watson and Wooden (2002) for more details. 
Report 2002). In other respects the sample composition is not significantly different from other estimates of the Australian population.

Each individual over the age of 15 in the selected households completed a personal questionnaire (PQ) which was administered in a face-to-face interview. All household members over the age of 15 were also asked to fill out a self-completion questionnaire (SCQ) which was left with individuals after completing the PQ and either completed immediately, returned by mail or picked up by the interviewer in the two weeks following the face-to-face interview. The survey protocol outlined a preferred strategy of conducting the face-to-face interviews separately with each member of the household. Since SCQs were primarily completed by individuals after the interviewer had left the household, there is no way to know whether or not individuals in the same household coordinated their responses in the SCQ. However, given the large amount of disagreement about incidence of financial difficulty documented in Table 1 below, it would appear that this was not the case.

The income, housing tenure, education and demographic data used in this analysis are from the PQ. The main variable definitions and some summary statistics are provided in Appendix Table A1. The SCQ asked about a range of negative financial events. Specifically, individuals were asked "Since January of 2002 did any of the following happen to you because of a shortage of money?" Possible responses included 1) an inability to pay utility bills on time; 2) an inability to pay the mortgage or rent on time; 3) pawning or selling something; 4) asking for financial help from family or friends; and 5) asking for help from welfare or community organizations. ${ }^{4}$ We refer to these various outcomes generically as "financial difficulty" or "financial problems." We use this information to create indicator $(0,1)$ variables for each financial problem as well as indicators for experiencing at least one and more than one form of financial difficulty. ${ }^{5} \quad$ Our sample consists of married (2714) and cohabiting (442) couples

\footnotetext{
${ }^{4}$ The HILDA Survey also asked about incidents of missed meals and an inability to heat the home. Missing meals is very uncommon amongst the couples in our sample, however, while heating is not a requirement for many Australian households. Consequently, we have chosen not to analyze these two outcomes in depth.

${ }^{5}$ We conducted factor analysis on the individual and household responses. We find that two factors account for most of the variation in these measures-one is a combination of the questions on utilities, mortgage payments, and help from friends and the other a combination of pawning, asking for help from welfare agencies, and asking for help from friends. The determinants of these factors
} 
in which both partners answered the PQ and the SCQ items relating to financial difficulty ${ }^{6}$

\section{Disagreement about Financial Difficulty}

Table 1 shows that the proportion of Australian couples reporting specific financial problems ranges from 19.5 percent (utilities) to 3.5 percent (welfare) with 26.7 percent of all couples reporting some form of financial difficulty. Partners often disagree, however, and more than half the time only one partner reports the problem. Although the incidence of financial problems is in general twice as high amongst cohabint couples, conditional on experiencing some form of financial difficulty they are no more likely to disagree than are married couples. ${ }^{7}$

[Table 1 about here]

Given the extent to which partners disagree about incidents of financial difficulty, it is interesting to look at the factors that explain this disagreement. To address this issue, we use a standard probit model to estimate the determinants of a couple's propensity to disagree about incidents of financial difficulty. Couples are coded as disagreeing whenever one person reports at least one incident of financial difficulty and his or her partner reports no incidents. These results (i.e., probit marginal effects and standard errors) are presented in column 2 of Table 2. Because approximately three in four couples agree that they have not experienced financial difficulty (see Table 1) however, estimates of disagreement based upon the entire sample of couples largely reflect the distinction between couples who do and do not experience any

are identical in sign and significance to the determinants of the 'any difficulty' measure which we analyze below and we therefore do not present the results for the derived variables from the factor analysis. These results are available from the authors upon request.

${ }^{6}$ Same sex couples and couples living with others who are not their own children have been excluded. Moreover, we deleted 459 couples in which at least one partner did not answer the PQ and a further 502 couples in which at least one partner did not completely answer the SCQ. The age and household characteristics of couples in our sample who did not complete the SCQ are generally similar to those who did. However, the couples who did not complete the SCQ have lower income, on average, than those who did and are more likely to be renting instead of holding a mortgage.

${ }^{7}$ One might worry that these results are driven by the longer average duration of married relationships relative to cohabiting relationships. However, results are substantially the same if we restrict our sample to couples who have been together for less than 10 years. 
financial problems at all. Consequently, we also present estimates of the propensity for at least one partner to report financial difficulty (column 1) as well as conditional estimates (column 3) based upon the restricted sample of couples in which at least one partner reports financial difficulty. ${ }^{8}$

[Table 2 about here]

Disagreement (see column 2) is more common in couples who are cohabiting, have less income from the wife, rent or are paying off a mortgage, and have been together for a shorter period. Higher education among wives is associated with a lower probability of disagreeing about financial difficulty, though husbands' education level has no significant effect on disagreement.

Not surprisingly, these patterns are sharpened when we consider the incidence of financial difficulty (see column 1). Financial difficulty is clearly related to a lack of financial resources (i.e., low income and educational attainment) as well as to increased needs (larger household size, rent and mortgage payments) with cohabiting couples reporting more problems in paying their bills than their married counterparts. When we condition on experiencing some form of financial difficulty (column 3 ), we find that couples are more likely to disagree about whether financial difficulty has occurred when the husband's income is higher, the household is smaller in terms of both adults and children and the couple has been together longer. ${ }^{9}$ For completeness, column 4 reports the estimates of the determinants of disagreement, conditioning on at least one person in the household not reporting financial stress. Taken together, these results show that households where both members report financial difficulty are distinctly different than those where only one member reports financial difficulty. The latter group, likewise, is different from those where neither partner reports financial difficulty. Consistent with previous results (see Table 1), given that they experience financial difficulty, cohabiting couples are no more likely to disagree about the experience than are married couples. They are more likely to

\footnotetext{
${ }^{8}$ Estimates are reported for our summary measure of any report of financial difficulty. Results for the specific financial problems are similar.

${ }^{9}$ Age of both husband and wife are insignificant in these regressions once we control for length of relationship. We therefore report regressions without age variables.
} 
experience financial difficulty, however, as is clear from column 4 of Table 2.

Why do partners disagree about whether the household has experienced financial difficulty? In what follows we explore four potential sources of disagreement: gender differences, information asymmetries, an individual (as opposed to a household) view of financial difficulty, and severity of material hardship. Each of these has implications for assessing household material hardship on the basis of individual accounts of household financial problems. In concluding, we also consider whether or not disagreement appears to be in some sense "random" in which case it can be ignored in standard estimation models.

It is worth noting at this point that our interest, in addition to documenting and exploring the source of this disagreement itself, is in whether disagreement limits the usefulness of reported financial difficulty as a signal of a household's level of material hardship. We adopt the standard interpretation that the latent variable in the propensity to report financial difficulty equation (column 1 of Table 2) is the underlying level of material hardship. Propensity to report financial difficulty increases with need and decreases with resources, consistent with this interpretation. In cases where a couple disagrees about the occurrence of a specific financial difficulty, we are not particularly interested in establishing the 'truth' of whether the actual financial difficulty occurred-even if we thought that this were possible. Rather, we are interested in understanding why it is that partners disagree and what this disagreement implies about the measurement of material hardship.

\subsection{A Bivariate Probit Model of Disagreement}

Consideration of those characteristics that are important in explaining each partner's report of financial difficulty is useful in testing a number of explanations for disagreement in reports of household financial difficulty. Consider the following model:

$$
\begin{aligned}
& y_{1 i}=X_{1 i} \beta_{1}+\mu_{i}+\varepsilon_{1 i}=X_{1 i} \beta_{1}+\gamma_{1 i} \\
& y_{2 i}=X_{2 i} \beta_{2}+\mu_{i}+\varepsilon_{2 i}=X_{2 i} \beta_{2}+\gamma_{2 i}
\end{aligned}
$$


where $y_{j i}$ is a latent variable which determines whether partner $j(j=1,2)$ reports financial difficulty, $X_{j i}$ is a vector of household and personal characteristics for both partners, ${ }^{10} \mu_{i}$ is an unobserved household-specific effect, and we assume that $\gamma_{1 i}$ and $\gamma_{2 i}$ are bivariate normally distributed error terms. $i$ indexes the household. In addition to being viewed as the propensity to report financial difficulty, the latent variable in (1) may be viewed as an underlying measure of the degree of material hardship experienced by the household. In the literature which uses reported financial difficulty to assess material hardship, the occurrence (and report) of financial difficulty is assumed to be increasing in material hardship.

This bivariate probit structure, in which there are common unobserved factors which affect the propensity of each member within a couple to report financial difficulty, seems natural in this case. Couples are likely to be matched on the basis of unobserved characteristics such as attitude towards risk, time preferences (which determine savings behavior), and approach to financial management which will influence the propensity to experience material hardship and to experience (and report) financial difficulty.

\subsubsection{Gender Differences}

Previous evidence suggests that husbands and wives often view household finances differently (Zagorsky, 2003; Dobbelsteen and Kooreman, 1997; Plug and van Praag, 1998) and disagreement about financial difficulty may stem from gender differences in perceptions of household finances and the nature of financial events. ${ }^{11}$ If this is the case we would expect significant gender differences in both the propensity to report and the determinants of financial difficulty. We find, however, that while women in cohabiting relationships are slightly less likely than their partners to report needing help from a welfare or community agency, on all other measures there are no significant gender differences in reported rates of financial difficulty (see Table 3).

\footnotetext{
${ }^{10}$ The model includes household financial resources (disposable income for each individual, housing tenure, and household size), partners' educational qualifications, length of relationship, and dummy variables indicating agreement/disagreement about who makes day-to-day decisions regarding household finances.

${ }^{11}$ Interestingly, sociological evidence suggests that men are more likely to report exposure to and be distressed by negative financial events (Conger, et al., 1993).
} 
[Table 3 about here]

Moreover, using our bivariate probit estimates, we also tested the joint equality of all coefficients across the equations for men and women. The results (reported in Table 4) indicate that there are very few systematic differences in men and women's reports of financial difficulty. ${ }^{12}$ Gender differences are important in understanding couples' propensity to report that they could not pay their utility bills. ${ }^{13}$ However, in all other cases, we fail to reject the hypothesis that the determinants of men's and women's reports of financial problems are the same. Thus, it does not appear that gender differences in perceptions of financial events are the source of the disagreement in partners' reports of the financial difficulty experienced by households. This is good news for surveys relying on a representative individual because women are often disproportionately likely to respond to questions about the household (see Zagorsky, 2003).

[Table 4 about here]

\subsubsection{Information Asymmetries}

The distribution of power between partners - which is often associated with bringing income into the household - can affect the organization of household finances including whether or not the couple chooses to maintain joint or separate bank accounts (Dobbelsteen and Kooreman, 1997; Pahl, 1995). Consequently, disagreement about whether or not the household has experienced financial difficulty may occur if one partner has less information about the household's financial position either because he or she is not involved in financial decision-making or because the household's finances are not fully integrated.

Table 5 documents the extent to which married and cohabiting couples maintain joint bank accounts and share financial decision-making about 1) day-to-day finances, 2) large purchases and 3) investments. The majority of couples agree that they share responsibility for day-to-day financial decisions and it is interesting that there

\footnotetext{
${ }^{12}$ Detailed coefficient estimates are in the appendix.

${ }^{13}$ This appears to be largely driven by gender differences in the effect of couples' disagreement about who makes the day-to-day financial decisions for the household.
} 
is much less disagreement about who in the family makes financial decisions than about whether the family has experienced financial difficulty. Not surprisingly, joint decision-making is more commonly used in making large purchases or investment decisions than in day-to-day financial management. Cohabiting couples are as (or even more) likely to share financial decision-making, but are much less likely to integrate their household finances. While 54.9 percent of married couples agree that they maintain some joint accounts, the same is true of only 27.6 percent of cohabiting couples. The majority of cohabiting couples manage their household finances using individual bank accounts only.

[Table 5 about here]

Using information about the shared responsibility for day-to-day financial decisions and the integration of household banking, we can assess whether disagreement about financial difficulty stems from information asymmetries between the two partners. ${ }^{14}$ We begin by incorporating these measures directly into our probit model of the determinants of a couple's propensity to disagree about experiencing negative financial events. ${ }^{15}$ The results indicate that - everything else equal - sharing day-to-day financial decision making and maintaining joint bank accounts are not significantly related to the probability that the couple will disagree about financial difficulty (see Table 6). In particular, undertaking joint decision making (the omitted category) and maintaining integrated bank accounts are generally associated with less disagreement (as one would expect), but these differences are not significant. At the same time, couples who disagree about who makes the day-today financial decisions in their household are 11 percentage points more likely to report some form of financial difficulty (see column 1). If we exclude households where both partners report financial problems, we also find that couples who disagree about who makes the day-to-day financial decisions are 10.6 percentage points more likely to have one member who reports a negative financial event (column 4).

[Table 6 about here]

\footnotetext{
${ }^{14}$ We do not separately consider shared responsibility for decisions about large purchases and investments because the overwhelming majority of couples agree that these decisions are made jointly. ${ }^{15}$ See Table 2.
} 
We also considered the incidence of financial difficulty reported by the subsample of 1053 married and 114 cohabiting couples who agree that only one partner makes the day-to-day financial decisions for the household. These results (presented in Table 7) indicate that decision makers are more likely to report financial difficulty than are their non-decision making partners, though this disparity is in general not significant. Individuals making day-to-day financial decisions are significantly more likely than their partners to indicate that the household was unable to pay its utility bills on time, however.

[Table 7 about here]

Finally, we reestimated equation (1) using decision-maker status - rather than gender - to classify partners. We then tested whether or not there are systematic differences in the determinants of decision makers' and non-decision makers' propensity to report financial difficulty. In all cases, we fail to reject the hypothesis that the determinants are jointly equal for the two partners. ${ }^{16}$

Fewer information asymmetries between partners do not seem to be related to less disagreement about financial problems. Couples who share financial decision making and maintain joint bank accounts are not significantly less likely to disagree about financial difficulty than couples who do not. Many surveys attempt to direct questions about household finances to the individual who is most knowledgeable about those finances. These results indicate that - at least with respect to financial difficulty - there is no evidence that responses about the household's financial position are related to the degree of information that the responding individual has about those finances.

\subsubsection{Individual vs. Household Hardship}

There is an extensive literature in economics which centers on the distribution of consumption within the household. It demonstrates that the nature of family preferences, partners' outside options, and the way in which income enters the household

\footnotetext{
${ }^{16}$ As before the null hypothesis is that the determinants of reported financial difficulty are jointly equal for the two partners.
} 
can all influence the way in which the household allocates resources to various family members. ${ }^{17}$ Because consumption within the household is not completely public, disagreement in reports of financial difficulty may also occur if partners are reporting financial events which are - at least in part - individual rather than household in nature.

Clearly, we do expect there to be an important common element in partners' reports of financial difficulty. This can be quantified by constructing the predicted probability that an individual will report financial difficulty conditional on his or her partner's response. If partners' responses about financial difficulty were completely independent then we would expect that the probability that partner $i$ reports some financial difficulty would not depend on what his or her partner had reported so that $P\left(H_{i}=1 \mid H_{j}=1\right)$ and $P\left(H_{i}=1 \mid H_{j}=0\right)$ would be approximately equal. This proposition is soundly rejected in the data (see Table 8).

[Table 8 about here]

Another way to test the same proposition is to use the estimated correlations from the bivariate probit model in (1). The estimated correlations are always highly significant, taking values from .72 for the summary measure of any financial difficulty to .80 for the measure of asking friends for financial help. Both of these tests indicate that there is an important common element in partners' reports of financial difficulty.

At the same time, financial difficulty may not be experienced equally by all members of the household and this might result in some disagreement about whether the household has in fact experienced the negative financial event. There is, for example, evidence that the income of a cohabiting partner contributes less than the income of a married partner to reducing the material hardship experienced by household heads (Bauman, 1999b). ${ }^{18}$ Consequently, we might expect that financial difficulty is more an individual- and less a household-specific experience in cohabiting couples

\footnotetext{
${ }^{17}$ See Behrman (1997) for a review of the empirical literature on the intrahousehold distribution of resources, while Bergstrom (1997) reviews theoretical models of the family.

${ }^{18}$ There is also evidence that cohabiting relationships are generally shorter than marriages and that on other dimensions - fertility, housework allocation, school enrollment and labor force participation - cohabiting couples fall somewhere between single individuals and married couples (see Bauman, 1999b for a review).
} 
and that disagreement between cohabiting partners would be higher. The evidence presented in Tables 1 and 2 does not support this proposition however. Though cohabiting couples experience more financial difficulty, conditional on experiencing some financial difficulty they are not more likely to disagree about it.

We might also expect that some reported events (such as borrowing money from friends or pawning something) are more individual experiences than others (for example, paying the rent or utilities). To investigate this, we define a measure of "public" hardship based on an inability to pay the utilities or rent/mortgage and a measure of "private" financial difficulty based on the need to pawn something or borrow money from friends. ${ }^{19}$ While disagreement about "private" experiences does seem to be more common (59.8 vs. 55.9 percent overall), the differences are small in magnitude and generally not significant (see Table 9).

[Table 9 about here]

In short, while there is strong evidence that there is an important householdspecific effect in reported financial difficulty, there is little evidence that within couples individual differences in experiences of financial difficulty are important in producing the extent of disagreement we observe in the data. Thus, it does seem to be the case that individuals are reporting about household rather than individual experiences.

\subsection{The Severity of Hardship}

Finally, disagreement between partners may be related to the severity of the underlying material hardship. Couples who disagree about whether they have been unable to pay the rent, for example, may be more financially constrained than couples who agree that they have paid the rent on time, but less constrained than couples who agree that they did not.

Indeed the above analysis suggests that relative to couples who agree that they experience financial difficulty, it is more financially-secure couples - i.e., those with higher incomes, living in smaller households, and in longer term relationships - who

\footnotetext{
${ }^{19}$ While this distinction is not completely clear cut, it nonetheless is useful in drawing distinctions between those forms of hardship which are more likely to be shared by others in the household and those which may not be.
} 
are more likely to disagree about incidents of material hardship (see column 3, Table 2). Further insight into this issue can be gained by directly examining the relationship between the likelihood of disagreement and a household's disposable income. In particular, Figure 1 shows that disagreement is most common in the middle income ranges and less common at the extremes of the distribution with high-income partners agreeing that they have not experienced financial difficulty and low-income partners agreeing that they have. ${ }^{20}$

[Figure 1 about here]

We can test the relationship between disagreement and the severity of hardship more formally by comparing a multivariate logit with an ordered probit model, using the non-nested model selection testing procedure outlined in Vuong (1989). In each case, the dependent variable takes value zero if hardship is reported by neither partner, one if it is reported by only one partner, and two if it is reported by both partners. ${ }^{21}$ The reasoning behind the test is that if disagreement reflects severity, then the categorical variable should exhibit an ordered feature, otherwise, it is best modelled as having no natural order. In the former case an ordered model (the multinomial probit) should fit the data better than an unordered model (the multinomial logit.) The null hypothesis is that the multinomial logit model fits the data at least as well as the ordered probit model. Rejection of the null implies that the ordered probit model, incorporating the severity hypothesis, is preferred.

The results (see Table 10) indicate that there is an ordering in the extent to which couples report financial difficulty. For married couples, the multinomial logit model is rejected (at 95 percent) in favor of the ordered probit model suggesting that there is a relationship between disagreement about financial difficulty and the severity of material hardship. Disagreement may be less closely related to the severity of

\footnotetext{
${ }^{20}$ In Figure 1, financial difficulty is defined as reporting any of the negative financial events. The proportion of couples in which neither partner reports financial difficulty $(0,0)$ is one minus the propotion of couples who disagree $((0,1)$ or $(1,0))$ minus the proportion of those who agree they have experienced financial difficulty $(1,1)$.

${ }^{21}$ The independent variables include: $\log$ of husband's and wife's income; number of children; number of adults; housing tenure; years the couple has been living together; each partner's education; and agreement/disagreement dummies regarding day-to-day financial decision-making. The models are tested separately for married and cohabiting couples.
} 
the hardship faced by cohabiting couples, however. For these couples, we cannot reject the null hypothesis of no ordering for the payment of mortgages/rent, pawning something, and seeking financial help from friends. ${ }^{22}$

[Table 10 about here]

Overall, these results imply that surveys which rely on a representative individual to report about household experiences of financial difficulty miss information that is available by asking both partners. Specifically, couples in the intermediate category of material hardship-where one reports financial difficulty while the other does not-may be mis-classified as experiencing hardship (or not experiencing hardship) depending upon which partner is surveyed. ${ }^{23}$

\section{Conclusions}

We use unique data in which both partners report about household finances to first demonstrate that there is often disagreement about whether the household has experienced financial difficulty, and, to second, test alternative explanations for this disagreement. Although previous research suggests that there are important differences in the way in which men and women perceive - and report about - household finances (see Zargorsky, 2003; Dobbelsteen and Kooreman, 1997; and Plug and van Praag, 1998), we find no evidence that gender differences in the propensity to report financial difficulty contribute to disagreement within couples about the household's experiences. Moreover, disagreement does not appear to be driven by partners taking an individual (rather than household) perspective with respect to financial difficulty

\footnotetext{
${ }^{22}$ This may be driven by the relatively small number of cohabiting couples rather than a fundamental differenence derriving from martital status.

${ }^{23}$ This difference may in part explain the divergence in the levels of reported financial difficulty in Australian households captured in the 1998-99 Household Expenditure Survey (HES) and in HILDA data (see Bray, 2001 and La Cava and Simon, 2003). The underlying questions in the two surveys are similar. However, Bray (2001) concludes that 6.6 percent of couples with dependent children reported some form of financial difficulty in 1998-99 using HES data. Other couple-headed households experienced somewhat less financial difficulty (pg. 29: Table 6). In contrast, HILDA estimates suggest that approximately 23.7 percent of couples experienced financial difficulty in the previous year. By relying on a representative individual to report on household experiences, the HES may not be capturing all the financial difficulty experienced by couples. HILDA's higher rates of negative financial events may also be due to the confidentiality of the self-completion questionaire or to the difference in time periods.
} 
and there is no evidence that disagreement stems from asymmetries in the extent to which partners are informed about the household's financial position. There is, however, strong evidence that disagreement may be related to the severity of the underlying material hardship. Couples who disagree that they have experienced financial difficulty seem to be less financially constrained than couples who agree that they have experienced hardship, but more constrained than couples who agree that they did not.

These results have a number of implications for standard surveys which collect information about the household's financial position from a representative individual. In particular, if disparity in partners' reports of financial difficulty were random noise, then it might be sensible to ignore it when estimating standard models. Unfortunately, our results clearly indicate that this is not the case. Disagreement is not random, but is closely related to the household's income level, demographic structure, housing status, and the nature of partners' relationship. More specifically, disagreement informs us about the severity of material hardship. This implies that surveys which rely upon a representative individual to report about financial difficulty are missing important information in understanding the degree of material hardship experienced by couples. Furthermore, if responses to questions about financial difficulty are being used to distinguish between households which do and do not experience material hardship, the high degree of disagreement indicates that many households will be mis-classified.

Given the strikingly large number of couples who disagree and the relatively low fit of our model of the propensity to report financial difficulty, it is clear that financial difficulty is a noisy signal of material hardship. If such a noisy signal is to be used to determine material hardship, it is clear that two measurements would be better than one, again pointing to a need to ask both members of the couple about their experiences of financial difficulty.

At the same time, the lack of significant gender differences in reported financial difficulty is encouraging given that women are disproportionately likely to respond to questions about the household (see Zagorsky, 2003). Moreover, there is a large common element in partners' reports of financial difficulty indicating that respondents are 
by and large reporting about household rather than personal experiences. Interestingly, however, information asymmetries between partners do not seem to be related to disagreement about financial difficulty. Although many surveys direct questions about household finances to the person who is most knowledgeable, our results indicate that there is little evidence that responses about the household's experiences of financial difficulty depend on the extent to which the responding individual claims to be informed about those finances.

Our results also point to a need to gather information about cohabiting couples as well as about married couples. U.S. surveys have not traditionally asked about cohabiting partners. The data we use provide information on both married and cohabiting couples and allow us to analyze whether or not they behave similarly. We find that cohabiting couples are no more likely to disagree about the experience of financial difficulty than their married counterparts, however they are more likely to experience financial difficulty, even after controlling for income and other household characteristics.

It is interesting to speculate on what might be happening in couples where one partner reports the occurrence of the financial difficulty but the other does not. Disagreement amongst partners regarding subjective evaluation of household finances is perhaps not surprising (see for example, Plug and van Praag, 1998), but in our case, survey respondents are being asked about the occurrence of an objective event in the preceding 10 months. It is in this light that we find the level of disagreement, particularly about things like failing to make a rent payment or failing to pay a utility bill, surprising.

This disagreement may arise because although the event did occur, one partner fails to recall it. For example, one partner may be simply ignorant of the event, e.g. one spouse borrowed money from family members without informing his or her partner. However, as we have shown, this ignorance of the event is not related to making expenditure decisions or integration of bank accounts. Likewise, the event may not have occurred, but one partner nonetheless recalls that event. A common example of this is 'telescoping', where the event did not occur in the specified time frame (since January, 2002) but did occur further in the past and is mistakenly recalled as having 
happened within the specified time frame. Both of these stories are consistent with our hypothesis that couples who disagree are suffering from intermediate levels of financial difficulty. If financial problems are neither persistent nor severe, then it is more likely that one member of the couple may fail to remember or may mis-report them.

\section{References}

[1] Bauman, K. 1999a. "Extended Measures of Well-Being: Meeting Basic Needs", Current Population Reports, Household Economic Studies, P70-67. Washington, DC: U.S. Bureau of the Census.

[2] Bauman, K. 1999b. "Shifting Family Definitions: The Effect of Cohabitation and Other Nonfamily Household Relationships on Measures of Poverty", Demography, Vol. 36(3), August, pp. 315-325.

[3] Behreman, J. 1997. "Intrahousehold Distribution and the Family", in Rozensweig, M.R. and O. Stark, editors, Handbook of Population and Family Economics, Amsterdam: Elsevier Science BV.

[4] Bergstrom, T. 1997. "A Survey of Theories of the Family", in Rozensweig, M.R. and O. Stark, editors, Handbook of Population and Family Economics, Amsterdam: Elsevier Science BV.

[5] Bray, J. Rob, 2001. "Hardship in Australia: An Analysis of Financial Stress indicators in the 1998-99 Australian Bureau of Statistics Household Expenditure Survey" Occasional Paper, No. 4, Department of Family and Community Services.

[6] Conger, R., Lorenz, F., Elder, G., Simons, R., Ge, X., 1993. "Husband and Wife Differences in Response to Undesirable Life Events", Journal of Health and Social Behavior, Vol. 34(1), March, pp. 71-88.

[7] Dobbelsteen, S., and Kooreman, P., 1997. "Financial Management, Bargaining and Efficiently within the Household: An Empirical Analysis", De Economist, Vol. 145(3), pp. 345-366.

[8] HILDA, 2002. HILDA Survey Annual Report 2002. Melbourne Institute of Applied Economic and Social Research, University of Melbourne.

[9] La Cava, G. and Simon, J., 2003. "A Tale of Two Surveys: Household Debt and Financial Constraints in Australia", Research Discussion Paper, 2003-008, Reserve Bank of Australia, July. 
[10] Layte, R., Maitre, B., Nolan, B. and Whelan, C., 2000. "Explaining Levels of Deprivation in the European Union", European Panel Analysis Working Paper No. 12, Institute for Social and Economic Research, University of Essex, Colchester, May 2000.

[11] Mayer, S. and Jencks, C., 1989. "Poverty and the Distribution of Material Hardship", Journal of Human Resources, Vol. XXIV(1), pp. 88-114.

[12] Pahl, Jan, 1995. "His Money, Her Money: Recent Research on Financial Organisation in Marriage", Journal of Economic Psychology, Vol. 16, pp. 361-376.

[13] Plug, E. and van Praag, B., 1998. "Similarity in Response Behavior between Household Members: An Application for Income Evaluation", Journal of Economic Psychology, Vol. 19, pp. 497-513.

[14] Watson, N., and Wooden, M. 2002. "The Household, Income and Labour Dynamics in Australia (HILDA) Survey: Wave 1 Survey Methodology", HILDA Project Technical Paper Series, No. 1/02, May, Melbourne Institute of Applied Economic and Social Research, University of Melbourne.

[15] Whelan, C., Layte, R., Maitre, B., and Nolan, B., 2001. "Persistent Income Poverty and Deprivation in the European Union: An Analysis of the First Three Waves of the European Community Household Panel", European Panel Analysis Working Paper No. 17, Institute for Social and Economic Research, University of Essex, Colchester, April 2001.

[16] Zagorsky, J., 2003. "Husbands' and Wives' View of Family Finances", Journal of Socio-Economics, Vol. 32, pp. 127-146. 
Table 1: Proportion of Couples Experiencing Financial Difficulty in Previous Year

\begin{tabular}{|c|c|c|c|c|c|}
\hline & Neither & $\begin{array}{c}\text { Husband } \\
\text { only }\end{array}$ & Wife only & Both & $\begin{array}{l}\text { Conditional } \\
\text { disagreement }\end{array}$ \\
\hline & \multicolumn{5}{|c|}{ All couples $(3156)$} \\
\hline Utilities & $80.5 \%$ & $5.1 \%$ & $6.1 \%$ & $8.3 \%$ & $57.6 \%$ \\
\hline Rent & $90.3 \%$ & $3.1 \%$ & $3.4 \%$ & $3.3 \%$ & $66.3 \%$ \\
\hline Pawn & $94.4 \%$ & $2.2 \%$ & $2.0 \%$ & $1.5 \%$ & $73.6 \%$ \\
\hline Friends & $86.5 \%$ & $4.0 \%$ & $4.2 \%$ & $5.3 \%$ & $60.6 \%$ \\
\hline Welfare & $96.5 \%$ & $1.1 \%$ & $1.5 \%$ & $1.0 \%$ & $71.4 \%$ \\
\hline \multirow{3}{*}{$\begin{array}{l}\text { Any } \\
\text { difficulty } \\
\text { More } \\
\text { than one } \\
\text { difficulty }\end{array}$} & $73.3 \%$ & $6.6 \%$ & $7.9 \%$ & $12.2 \%$ & $54.2 \%$ \\
\hline & $85.3 \%$ & $4.1 \%$ & $4.7 \%$ & $5.9 \%$ & $59.8 \%$ \\
\hline & \multicolumn{5}{|c|}{ Married couples (2714) } \\
\hline Utilities & $83.5 \%$ & $4.5 \%$ & $5.2 \%$ & $6.8 \%$ & $58.6 \%$ \\
\hline Rent & $92.1 \%$ & $2.6 \%$ & $2.9 \%$ & $2.4 \%$ & $69.2 \%$ \\
\hline Pawn & $95.5 \%$ & $1.8 \%$ & $1.6 \%$ & $1.1 \%$ & $76.0 \%$ \\
\hline Friends & $89.7 \%$ & $3.4 \%$ & $2.9 \%$ & $4.1 \%$ & $60.6 \%$ \\
\hline Welfare & $97.5 \%$ & $0.9 \%$ & $0.9 \%$ & $0.6 \%$ & $74.6 \%$ \\
\hline \multirow{3}{*}{$\begin{array}{l}\text { Any } \\
\text { difficulty } \\
\text { More } \\
\text { than one } \\
\text { difficulty }\end{array}$} & $77.0 \%$ & $6.1 \%$ & $6.9 \%$ & $10.1 \%$ & $56.3 \%$ \\
\hline & $88.5 \%$ & $3.5 \%$ & $3.6 \%$ & $4.4 \%$ & $61.7 \%$ \\
\hline & \multicolumn{5}{|c|}{ Cohabiting couples (442) } \\
\hline Utilities & $62.0 \%$ & $8.8 \%$ & $12.0 \%$ & $17.2 \%$ & $54.8 \%$ \\
\hline Rent & $79.2 \%$ & $6.1 \%$ & $6.3 \%$ & $8.4 \%$ & $60.0 \%$ \\
\hline Pawn & $87.1 \%$ & $4.5 \%$ & $4.3 \%$ & $4.1 \%$ & $68.4 \%$ \\
\hline Friends & $66.7 \%$ & $7.9 \%$ & $12.2 \%$ & $13.2 \%$ & $60.6 \%$ \\
\hline Welfare & $89.8 \%$ & $1.8 \%$ & $5.0 \%$ & $3.4 \%$ & $66.7 \%$ \\
\hline $\begin{array}{l}\text { Any } \\
\text { difficulty }\end{array}$ & $50.7 \%$ & $9.7 \%$ & $14.0 \%$ & $25.6 \%$ & $48.2 \%$ \\
\hline $\begin{array}{l}\text { More } \\
\text { than one } \\
\text { difficulty }\end{array}$ & $66.1 \%$ & $7.7 \%$ & $11.3 \%$ & $14.9 \%$ & $56.0 \%$ \\
\hline
\end{tabular}

Conditional disagreement column is the percentage of couples who disagree within households where at least one member reports financial difficulty. 
Table 2. Determinants of Financial Difficulty and Disagreement about Financial Difficulty

\begin{tabular}{|c|c|c|c|c|}
\hline \multirow[b]{2}{*}{$\begin{array}{l}\text { Dependent } \\
\text { Variable equals } \\
\text { one if: }\end{array}$} & \multicolumn{2}{|c|}{ All couples } & \multicolumn{2}{|c|}{$\begin{array}{l}\text { Only couples for whom } \\
\text { at least one member } \\
\text { of the couple reports: }\end{array}$} \\
\hline & $\begin{array}{l}\text { Any report of } \\
\text { financial } \\
\text { difficulty }\end{array}$ & $\begin{array}{l}\text { Couple } \\
\text { disagree }\end{array}$ & $\begin{array}{l}\text { Couple } \\
\text { disagree }\end{array}$ & $\begin{array}{l}\text { Couple } \\
\text { disagree }\end{array}$ \\
\hline Husband's Income & $\begin{array}{l}-.071^{* *} \\
(.011)\end{array}$ & $\begin{array}{l}-.0058 \\
(.0083)\end{array}$ & $\left(_{(.025)}^{.13}\right)^{* *}$ & $-.024^{* *}$ \\
\hline Wife's Income & $\begin{array}{l}-.026^{* *} \\
(.0084)\end{array}$ & $\begin{array}{l}-.013^{* *} \\
(.0063)\end{array}$ & $\begin{array}{l}.013 \\
(.021)\end{array}$ & $-{ }_{(.0069)}^{.016}$ \\
\hline Number of kids &.$_{(.042}^{* *}$ & $\begin{array}{l}.0084 \\
(.0058)\end{array}$ & $\begin{array}{l}-.044^{* *} \\
(.016)\end{array}$ & ${(.02)^{* *}}^{* 0066)}$ \\
\hline Number of adults & ${ }_{(.0413)}^{* *}$ & $\begin{array}{l}.0067 \\
(.010)\end{array}$ & $\begin{array}{l}-.071^{* *} \\
(.031)\end{array}$ & $\begin{array}{l}.015 \\
(.011)\end{array}$ \\
\hline Renting & ${ }^{.30} 0^{* *}$ & ${ }^{.0600^{* *}}$ & $\begin{array}{l}-.28^{* *} \\
(.054)\end{array}$ &.$_{(.031)}^{* *}$ \\
\hline Unpaid mortgage & $(.021)^{* *}$ & ${ }_{(.035)}{ }^{* *}$ & $\begin{array}{l}-.16^{* *} \\
(.053)\end{array}$ & $\begin{array}{l}.048^{* *} \\
(.018)\end{array}$ \\
\hline $\begin{array}{l}\text { Years living } \\
\text { together }\end{array}$ & $\begin{array}{l}-.0057^{* *} \\
(.00077)\end{array}$ & $\begin{array}{l}-.0025^{* *} \\
(.00059)\end{array}$ & $\begin{array}{l}.0038^{*} \\
(.0020)\end{array}$ & $-.0032^{* *}$ \\
\hline $\begin{array}{l}\text { Wife university } \\
\text { educated }\end{array}$ & $\begin{array}{l}-.074^{* *} \\
(.020)\end{array}$ & $\begin{array}{l}-.028^{*} \\
(.016)\end{array}$ & $\begin{array}{l}.056 \\
(.053)\end{array}$ & $-.042^{* *}$ \\
\hline $\begin{array}{l}\text { Husband univer- } \\
\text { sity educated }\end{array}$ & $\begin{array}{l}-.048^{* *} \\
(.021)\end{array}$ & $\begin{array}{l}-.025 \\
(.016)\end{array}$ & $\begin{array}{l}.013 \\
(.053)\end{array}$ & $-.033^{*}$ \\
\hline cohabiting &.$\left._{(.029)}\right)^{* *}$ & $\begin{array}{l}.038^{*} \\
(.022) \\
\end{array}$ & $\begin{array}{c}-.0097 \\
(.050) \\
\end{array}$ & $\begin{array}{l}.073^{* *} \\
(.027)\end{array}$ \\
\hline sample size & 3044 & 3044 & 811 & 2670 \\
\hline pseudo r-squared & $15.4 \%$ & $3.9 \%$ & $8.3 \%$ & $7.9 \%$ \\
\hline log likelihood value & -1492.1 & -1203.15 & -512.41 & -1095.7 \\
\hline
\end{tabular}

Coefficients are probit marginal effects (standard errors in parentheses). In column 1, the dependent variable equals 1 if either member of the couple reports financial difficulty. In columns 2 through 4 , the dependent variable equals 1 if the couple disagree about financial difficulty. Columns 1 and 2 use the full sample, column 3 uses only the sample for whom the dependent variable column 1 equals one, while column 4 uses only the sample for whom the dependent variable from column 1 equals 0 . All estimation samples include both married and cohabiting couples. Income variables are included in log form which results in dropping 108 observations where either the husband or wife has zero income. Four observations having missing data on the relationship length. These are also dropped for these regressions.

${ }^{*}$ and ${ }^{* *}$ indicate significance at $90 \%$ and $95 \%$ confidence, respectively. 
Table 3: Incidence of Financial Difficulty by Sex

\begin{tabular}{|l|c|c|c|c|}
\hline & \multicolumn{2}{|c|}{ Married Couples } & \multicolumn{2}{c|}{ Cohabiting Couples } \\
& Women & Men & Women & Men \\
\hline Utilities & $12.0 \%$ & $11.3 \%$ & $29.2 \%$ & $26.0 \%$ \\
Mortgage & $5.3 \%$ & $5.0 \%$ & $14.7 \%$ & $14.5 \%$ \\
Pawn & $2.7 \%$ & $2.8 \%$ & $8.4 \%$ & $8.6 \%$ \\
Friends & $6.9 \%$ & $7.4 \%$ & $25.3 \%$ & $21.0 \%$ \\
Welfare & $1.5 \%$ & $1.5 \%$ & $8.4 \%$ & $5.2 \%^{*}$ \\
Any & $16.9 \%$ & $16.2 \%$ & $40.0 \%$ & $35.3 \%$ \\
difficulty & & & & \\
More one & $8.0 \%$ & $8.0 \%$ & $26.2 \%$ & $22.6 \%$ \\
than one \\
difficulty
\end{tabular}

Table 4: Testing the Equality of Bi-variate Probit Coefficients Across Sex (p-values)

\begin{tabular}{|l|c|c|}
\hline & Married Couples & $\begin{array}{c}\text { Cohabiting } \\
\text { Couples }\end{array}$ \\
\hline Utilities & $.047^{* *}$ & $.048^{* *}$ \\
Mortgage & 0.78 & 0.95 \\
Pawn & 0.49 & 0.95 \\
Friends & 0.33 & 0.55 \\
Welfare & 0.39 & $\mathrm{n} / \mathrm{a}$ \\
Any difficulty & $.034^{* *}$ & 0.41 \\
More than one & 0.57 & 0.24 \\
difficulty & & \\
\hline
\end{tabular}

The model on welfare for cohabiting couples failed to converge. 
Table 5: Financial Decision-making and Integration of Banking by Marital Status (Cell Size and Percent)

\begin{tabular}{|c|c|c|c|}
\hline & Total & Married couples & Cohabiting couples \\
\hline & \multicolumn{2}{|c|}{ Who makes day-to-day financial decisions } \\
\hline Husband & $286(9.1 \%)$ & $248(9.1 \%)$ & $38(8.6 \%)$ \\
Wife & $881(27.9 \%)$ & $805(30.0 \%)$ & $76(17.2 \%)$ \\
Both & $1825(57.8 \%)$ & $1525(56.2 \%)$ & $300(67.9 \%)$ \\
Disagree & $86(2.7 \%)$ & $75(2.8 \%)$ & $11(2.5 \%)$ \\
Other & $78(2.5 \%)$ & $61(2.3 \%)$ & $17(3.9 \%)$ \\
\hline Husband & Who makes decisions about large purchases \\
\hline Wife & $197(6.2 \%)$ & $165(6.1 \%)$ & $32(7.2 \%)$ \\
Both & $46(1.5 \%)$ & $37(1.4 \%)$ & $9(2.0 \%)$ \\
Disagree & $2723(86.3 \%)$ & $2348(86.5 \%)$ & $375(84.8 \%)$ \\
Other & $50(1.6 \%)$ & $47(1.7 \%)$ & $3(0.7 \%)$ \\
\hline Husband & $140(4.4 \%)$ & $117(4.3 \%)$ & $23(5.2 \%)$ \\
\hline Wife & $313(9.9 \%)$ & $276(10.2 \%)$ & $37(8.4 \%)$ \\
Both & $104(3.3 \%)$ & $83(3.1 \%)$ & $21(4.8 \%)$ \\
Disagree & $2523(79.9 \%)$ & $2181(80.4 \%)$ & $342(77.4 \%)$ \\
Other & $63(2.0 \%)$ & $46(1.7 \%)$ & $17(3.9 \%)$ \\
\hline Only joint & $153(4.9 \%)$ & $128(4.7 \%)$ & $25(5.7 \%)$ \\
\hline Only individual & $1019(32.3 \%)$ & $986(36.3 \%)$ & $33(7.5 \%)$ \\
Combination & $553(17.5 \%)$ & $328(12.1 \%)$ & $225(50.9 \%)$ \\
Disagree & $593(18.8 \%)$ & $504(18.6 \%)$ & $89(20.1 \%)$ \\
Missing or no bank accounts & $8(0.25 \%)$ & $8(0.29 \%)$ & $95(21.5 \%)$ \\
\hline Total & 3156 & 2714 & 0 \\
\hline & \multicolumn{3}{|c|}{ Bank accounts } \\
\hline
\end{tabular}


Table 6. Determinants of Financial Difficulty and Disagreement about Financial Difficulty: Information and Financial Integration (Probit Marginal Effects and Standard Errors)

\begin{tabular}{|c|c|c|c|c|}
\hline & \multirow{2}{*}{\multicolumn{2}{|c|}{ All couples }} & \multicolumn{2}{|c|}{$\begin{array}{l}\text { Only couples for whom } \\
\text { at least one member } \\
\text { of the couple reports: }\end{array}$} \\
\hline & & & $\begin{array}{l}\text { financial } \\
\text { difficulty }\end{array}$ & $\frac{\text { no financial }}{\text { difficulty }}$ \\
\hline $\begin{array}{l}\text { Dependent } \\
\text { Variable equals } \\
\text { one if: }\end{array}$ & $\begin{array}{l}\text { Any report of } \\
\text { financial } \\
\text { difficulty }\end{array}$ & $\begin{array}{l}\text { Couple } \\
\text { disagree }\end{array}$ & $\begin{array}{l}\text { Couple } \\
\text { disagree }\end{array}$ & $\begin{array}{c}\text { Couple } \\
\text { disagree }\end{array}$ \\
\hline \multicolumn{4}{|c|}{ The role of day-to-day decision making. } & \\
\hline $\begin{array}{l}\text { Disagree } \\
\text { day-to-day }\end{array}$ & $.11^{* *}$ & .070 & $\begin{array}{l}.052 \\
(.099)\end{array}$ & $i^{.1057)}$ \\
\hline Missing day-to-day & $\begin{array}{l}.056 \\
(.056)\end{array}$ & $\begin{array}{l}.039 \\
(.044)\end{array}$ & $\begin{array}{l}.032 \\
(.10)\end{array}$ & $\begin{array}{l}.060 \\
(.052)\end{array}$ \\
\hline $\begin{array}{l}\text { Agree day-to-day } \\
\text { individual }\end{array}$ & $\begin{array}{c}-.0020 \\
(.017)\end{array}$ & $\begin{array}{l}.0047 \\
(.013)\end{array}$ & $\begin{array}{l}.027 \\
(.039)\end{array}$ & $\begin{array}{l}.0046 \\
(.015)\end{array}$ \\
\hline $\begin{array}{l}\text { pseudo r-squared } \\
\text { log likelihood value }\end{array}$ & $\begin{array}{c}15.6 \% \\
-1489.6\end{array}$ & $\begin{array}{c}4.1 \% \\
-1201.42\end{array}$ & $\begin{array}{c}8.4 \% \\
-512.93\end{array}$ & $\begin{array}{c}8.2 \% \\
-1092.89\end{array}$ \\
\hline \multicolumn{4}{|c|}{ The role of banking. } & \\
\hline Disagree banking & $\begin{array}{l}-.018 \\
(.025)\end{array}$ & -.013 & $\begin{array}{l}-.045 \\
(.054)\end{array}$ & $\begin{array}{l}-.039 \\
(.11)\end{array}$ \\
\hline Missing banking & $\begin{array}{l}.025 \\
(.16)\end{array}$ & $\begin{array}{l}-.016 \\
(.12)\end{array}$ & $\begin{array}{l}-.27 \\
(.29)\end{array}$ & $\begin{array}{l}-.018 \\
(.021)\end{array}$ \\
\hline Integrated banking & $\frac{-.032}{(.024)}$ & $\begin{array}{l}-.021 \\
(.018)\end{array}$ & $\begin{array}{l}-.056 \\
(.050)\end{array}$ & $\begin{array}{l}-.032 \\
(.020)\end{array}$ \\
\hline pseudo r-squared & $15.5 \%$ & $4.0 \%$ & $8.5 \%$ & $8.0 \%$ \\
\hline log likelihood value & -1491.1 & -1202.43 & -512.41 & -1094.47 \\
\hline
\end{tabular}

Table 7: Incidence of Financial Difficulty by Decision-maker Status

\begin{tabular}{|l|c|c|c|c|c|c|}
\hline \multirow{2}{*}{} & \multicolumn{2}{|c|}{ All couples } & \multicolumn{2}{c|}{ Married couples } & \multicolumn{2}{c|}{ Cohabiting couples } \\
& \multicolumn{2}{|c|}{1167} & \multicolumn{2}{c|}{1053} & \multicolumn{2}{|c|}{114} \\
& DM & non-DM & DM & non-DM & DM & non-DM \\
\hline Utilities & $14.1 \%^{* *}$ & 11.4 & $12.2 \%$ & $10.3 \%$ & $32.5 \%^{*}$ & $21.9 \%$ \\
Mortgage & $6.1 \%$ & $5.0 \%$ & $5.2 \%$ & $4.4 \%$ & $14.0 \%$ & $10.5 \%$ \\
Pawn & $3.3 \%$ & $3.4 \%$ & $2.8 \%$ & $2.6 \%$ & $7.0 \%$ & $11.4 \%$ \\
Friends & $9.3 \%$ & $7.9 \%$ & $7.3 \%$ & $6.5 \%$ & $28.1 \%$ & $21.1 \%$ \\
Welfare & $1.8 \%$ & $1.5 \%$ & $1.1 \%$ & $1.3 \%$ & $7.9 \%^{*}$ & $2.6 \%$ \\
Any diffi- & $20.1 \%^{* *}$ & $16.0 \%$ & $17.8 \%^{* *}$ & $14.1 \%$ & $42.1 \%$ & $34.2 \%$ \\
culty than & & & & & & \\
More tha & $9.3 \%$ & $8.7 \%$ & $7.4 \%$ & $7.3 \%$ & $26.3 \%$ & $21.1 \%$ \\
one difficulty & & & & & & \\
\hline
\end{tabular}

* and ${ }^{* *}$ indicate significant differences between the report of negative financial events between decision-maker and non-decision maker at $90 \%$ and $95 \%$ confidence, respectively. Sample is couples who agree that day-to-day financial decisions are made by one individual (and they agree who that individual is.) 
Table 8. Incidence of Reported Financial Difficulty Conditional on Partner's Reported Difficulty by Sex

\begin{tabular}{|c|c|c|c|c|c|c|}
\hline & $\widehat{p}_{h=0}^{w}$ & $\widehat{p}_{h=1}^{w}$ & $\begin{array}{c}\widehat{p}_{h=1}^{w}- \\
\widehat{p}_{h=0}^{w}\end{array}$ & $\widehat{p}_{u=0}^{h}$ & $\widehat{p}_{w=1}^{h}$ & $\begin{array}{c}\widehat{p}_{w=1}^{h}- \\
\widehat{p}_{w=0}^{h}\end{array}$ \\
\hline Utilities & $7.1 \%$ & $61.8 \%$ & $54.8 \%^{* *}$ & $6.0 \%$ & $57.5 \%$ & $51.5 \%^{* *}$ \\
Married & $5.8 \%$ & $60.3 \%$ & $54.4 \%^{* *}$ & $5.1 \%$ & $56.9 \%$ & $51.8 \%^{* *}$ \\
Cohabiting & $16.2 \%$ & $66.1 \%$ & $49.9 \%^{* *}$ & $12.5 \%$ & $58.9 \%$ & $46.5 \%^{* *}$ \\
Mortgage & $3.6 \%$ & $51.5 \%$ & $47.9 \%^{* *}$ & $3.3 \%$ & $49.3 \%$ & $46.0 \%^{* *}$ \\
Married & $3.0 \%$ & $48.5 \%$ & $45.5 \%^{* *}$ & $2.7 \%$ & $45.8 \%$ & $43.1 \%^{* *}$ \\
Cohabiting & $7.4 \%$ & $57.8 \%$ & $50.4 \%^{* *}$ & $7.2 \%$ & $56.9 \%$ & $49.8 \%^{* *}$ \\
Pawn & $2.1 \%$ & $40 . \%$ & $38.8 \%^{* *}$ & $2.2 \%$ & $42.7 \%$ & $40.5 \%^{* *}$ \\
Married & $1.7 \%$ & $37.7 \%$ & $36.0 \%^{* *}$ & $1.8 \%$ & $39.7 \%$ & $37.9 \%^{* *}$ \\
Cohabiting & $4.7 \%$ & $47.4 \%$ & $42.7 \%^{* *}$ & $4.9 \%$ & $48.6 \%$ & $43.7 \%^{* *}$ \\
Friends & $4.6 \%$ & $57.1 \%$ & $52.5 \%^{* *}$ & $4.4 \%$ & $56.0 \%$ & $51.2 \%^{* *}$ \\
Married & $3.1 \%$ & $54.7 \%$ & $51.6 \%^{* *}$ & $3.6 \%$ & $58.5 \%$ & $54.9 \%^{* *}$ \\
Cohabiting & $15.5 \%$ & $62.4 \%$ & $46.9 \%^{* *}$ & $10.6 \%$ & $51.8 \%$ & $41.2 \%^{* *}$ \\
Welfare & $1.5 \%$ & $49.2 \%$ & $47.7 \%^{* *}$ & $1.1 \%$ & $40.5 \%$ & $39.4 \%^{* *}$ \\
Married & $0.9 \%$ & $40.5 \%$ & $39.5 \%^{* *}$ & $0.9 \%$ & $40.5 \%$ & $39.5 \%^{* *}$ \\
Cohabiting & $5.3 \%$ & $65.2 \%$ & $60.0 \%^{* *}$ & $2.0 \%$ & $40.5 \%$ & $38.5 \%^{* *}$ \\
Any difficulty & $9.7 \%$ & $64.9 \%$ & $55.2 \%^{* *}$ & $8.3 \%$ & $60.9 \%$ & $52.6 \%^{* *}$ \\
Married & $8.2 \%$ & $62.2 \%$ & $54.0 \%^{* *}$ & $7.4 \%$ & $59.5 \%$ & $52.1 \%^{* *}$ \\
Cohabiting & $21.7 \%$ & $72.4 \%$ & $50.8 \%^{* *}$ & $16.1 \%$ & $64.6 \%$ & $48.5 \%^{* *}$ \\
More than & $5.2 \%$ & $58.9 \%$ & $53.7 \%^{* *}$ & $4.6 \%$ & $55.9 \%$ & $51.3 \%^{* *}$ \\
one difficulty & $3.9 \%$ & $55.6 \%$ & $51.7 \%^{* *}$ & $3.8 \%$ & $55.3 \%$ & $51.5 \%^{* *}$ \\
Married & $14.6 \%$ & $66.0 \%$ & $51.4 \%^{* *}$ & $10.4 \%$ & $56.9 \%$ & $46.5 \%^{* *}$ \\
Cohabiting & $1.9 \%$
\end{tabular}

Note: $\widehat{p}_{h=1}^{w}$ is the probability of observing a positive response from the wife to the presence of the negative event conditional on the husband having reported the event. The other probabilities are defined similarly. 
Table 9: Incidence of Disagreement about Private and Public Financial Difficulty by Type of Household Decision-making

\begin{tabular}{|c|c|c|c|c|}
\hline & \multicolumn{2}{|c|}{ Private Difficulty } & \multicolumn{2}{|c|}{ Public Difficulty } \\
\hline & Incidence & Disagreement & Incidence & Disagreement \\
\hline All couples & $\begin{array}{c}502 \\
(13.9 \%)\end{array}$ & $59.8 \%$ & $\begin{array}{c}656 \\
(20.8 \%)\end{array}$ & $55.9 \%$ \\
\hline \multicolumn{5}{|l|}{ Day-to-day decision making } \\
\hline $\begin{array}{l}\text { Couples who agree about how } \\
\text { decisions are made }(2992)\end{array}$ & $\begin{array}{c}464 \\
(15.5 \%)\end{array}$ & $60.3 \%$ & $\begin{array}{c}612 \\
(20.5 \%)\end{array}$ & $56.2 \%$ \\
\hline $\begin{array}{l}\text { Couples who disagree about } \\
\text { how decisions are made }(164)\end{array}$ & $\begin{array}{c}39 \\
(23.8 \%)\end{array}$ & $53.8 \%$ & $\begin{array}{c}45 \\
(27.4 \%)\end{array}$ & $51.1 \%$ \\
\hline \multicolumn{5}{|c|}{ Decision making about large purchases } \\
\hline $\begin{array}{l}\text { Couples who agree about how } \\
\text { decisions are made }(2966)\end{array}$ & $\begin{array}{c}469 \\
(15.8 \%)\end{array}$ & $59.7 \%$ & $\begin{array}{c}610 \\
(20.6 \%)\end{array}$ & $55.6 \%$ \\
\hline $\begin{array}{l}\text { Couples who disagree about } \\
\text { how decisions are made (190) }\end{array}$ & $\begin{array}{c}34 \\
(17.9 \%)\end{array}$ & $61.8 \%$ & $\begin{array}{c}47 \\
(24.7 \%)\end{array}$ & $59.6 \%$ \\
\hline \multicolumn{5}{|c|}{ Decision making about investments } \\
\hline $\begin{array}{l}\text { Couples who agree about how } \\
\text { decisions are made }(2940)\end{array}$ & $\begin{array}{c}466 \\
(15.9 \%)\end{array}$ & $59.7 \%$ & $\begin{array}{c}602 \\
(20.5 \%)\end{array}$ & $56.0 \%$ \\
\hline $\begin{array}{l}\text { Couples who disagree about } \\
\text { how decisions are made }(216) \\
\text { Integrated banking }\end{array}$ & $\begin{array}{c}37 \\
(17.1 \%)\end{array}$ & $62.2 \%$ & $\begin{array}{c}55 \\
(25.5 \%)\end{array}$ & $54.5 \%$ \\
\hline $\begin{array}{l}\text { Couples who use joint } \\
\text { accounts/agreement }(1612)\end{array}$ & $\begin{array}{c}214 \\
(13.3 \%)\end{array}$ & $57.9 \%$ & $\begin{array}{c}286 \\
(17.7 \%)\end{array}$ & $59.1 \%$ \\
\hline $\begin{array}{l}\text { Couples who use only } \\
\text { individual accounts/ } \\
\text { agreement }(1544)\end{array}$ & $\begin{array}{c}289 \\
(18.7 \%)\end{array}$ & $61.2 \% * *$ & $\begin{array}{c}371 \\
(24.0 \%)\end{array}$ & $53.4 \%$ \\
\hline
\end{tabular}

** indicates that disagreement about private stress is significantly larger than disagreement about public stress for couples who disagree about bank account arrangements or who do not have integrated banking at the $95 \%$ confidence level.

Table 10: Model Selection Tests: Multinomial Logit vs. Ordered Probit (t-statistics)

\begin{tabular}{|l|c|c|}
\hline $\begin{array}{l}\text { Dependent } \\
\text { Variable }\end{array}$ & $\begin{array}{c}\text { Married } \\
\text { Couples }\end{array}$ & $\begin{array}{c}\text { Cohabiting } \\
\text { Couples }\end{array}$ \\
\hline Utilities & $3.00^{* *}$ & $2.05^{* *}$ \\
Mortgage & $1.87^{*}$ & 1.54 \\
Pawn & $2.42^{* *}$ & 1.59 \\
Friends & $2.50^{* *}$ & 1.49 \\
Welfare & $2.28^{* *}$ & $2.15^{* *}$ \\
Any difficulty & $3.06^{* *}$ & $2.09^{* *}$ \\
More than one dif- & $2.75^{* *}$ & 1.35 \\
ficulty & & \\
\hline
\end{tabular}

* and ${ }^{* *}$ indicate significant differences between the ordered probit and multinomial logit models at $90 \%$ and $95 \%$ confidence, respectively. 


\section{Appendix Tables}

\section{Notes on tables}

Entries in tables A2 to A8 are marginal changes in indicated probability for a small change in the relevant independent variable. Changes are evaluated at the means of the variables. Dummy variables are evaluated as changes from () to 1 at the means of the other variables.

The column labelled $P\left(w_{0}, h_{1}\right)$ contains the marginal changes in the probability that the wife does not report the negative financial event while the husband does. The other columns are defined analogously. The marginal change $P\left(w_{0}, h_{0}\right)$, which is not given in the table, may be calculated from the table entries as $P\left(w_{0}, h_{0}\right)=-P\left(w_{1}, h_{0}\right)-P\left(w_{0}, h_{1}\right)-P\left(w_{1}, h_{1}\right)$ for each row. Likewise the marginal effects for the individual marginal probabilities $P\left(w_{1}\right)$ may be calculated as $P\left(w_{1}\right)=P\left(w_{1}, h_{1}\right)+P\left(w_{1}, h_{0}\right)$.

For the models using the question about pawning and the question about welfare, the marginal effects were estimated very imprecisely when we included all four dummy variables for day-to-day decision making. Since husband and wife individual decision-making were statistically identical to joint decision making, we combined these categories. We also failed to reject that there was any difference between missing decision-making information and disagreement about decision-making for couples for these measures. Thus, we pooled this category as well for those estimates. This does not affect the results presented above in

Table 5 . 
Table A1. Variable definitions and sample means

\begin{tabular}{|c|c|c|}
\hline Variable & Definition & $\begin{array}{c}\text { Sample mean } \\
\text { (standard deviation) }\end{array}$ \\
\hline Husband's Income & $\begin{array}{l}\text { Financial year, after-tax disposable } \\
\text { income. Includes child care benefit and } \\
\text { family tax benefits. }\end{array}$ & $\begin{array}{c}\$ 33,965 \\
(26,237)\end{array}$ \\
\hline Wife's Income & as above & $\begin{array}{c}\$ 19,329 \\
(16,692)\end{array}$ \\
\hline $\begin{array}{l}\text { Log of husband's } \\
\text { income }\end{array}$ & & $\begin{array}{l}10.17 \\
(0.85)\end{array}$ \\
\hline $\begin{array}{l}\text { Log of wife's in- } \\
\text { come }\end{array}$ & & $\begin{array}{l}9.52 \\
(1.01)\end{array}$ \\
\hline Number of kids & $\begin{array}{c}\text { Number of children under age } 15 \text { living in } \\
\text { the household }\end{array}$ & $\begin{array}{l}0.82 \\
(1.14)\end{array}$ \\
\hline Number of adults & $\begin{array}{c}\text { Number of individuals over age } 14 \text { living } \\
\text { in the household }\end{array}$ & $\begin{array}{l}2.30 \\
(0.65)\end{array}$ \\
\hline Renting & $\begin{array}{c}=1 \text { if couple is paying rent to live in the } \\
\text { house in which they live }\end{array}$ & $\begin{array}{l}0.165 \\
(0.371)\end{array}$ \\
\hline Unpaid mortgage & $\begin{array}{c}=1 \text { if couple owns own home but are still } \\
\text { paying off mortgage }\end{array}$ & $\begin{array}{l}0.38 \\
(0.49)\end{array}$ \\
\hline $\begin{array}{l}\text { Years living to- } \\
\text { gether }\end{array}$ & $\begin{array}{l}\text { For married couples, time since marriage } \\
\text { plus the reported amount of time the } \\
\text { couple lived together before marriage, in } \\
\text { years. For cohabiting couples, the length } \\
\text { of time, in years, that they have lived } \\
\text { with current partner. Calculated from } \\
\text { woman's responses in both cases. }\end{array}$ & $\begin{array}{l}20.62 \\
(15.2)\end{array}$ \\
\hline $\begin{array}{l}\text { Wife university } \\
\text { educated }\end{array}$ & $\begin{array}{l}=1 \text { if wife's highest level of achieved } \\
\text { education is bachelor's degree or higher }\end{array}$ & $\begin{array}{l}0.207 \\
(0.405)\end{array}$ \\
\hline $\begin{array}{l}\text { Husband university } \\
\text { educated }\end{array}$ & $\begin{array}{l}=1 \text { if husband's highest level of achieved } \\
\text { education is bachelor's degree or higher }\end{array}$ & $\begin{array}{l}0.222 \\
(0.416)\end{array}$ \\
\hline & $\begin{array}{c}=1 \text { if in an unmarried, cohabiting } \\
\text { relationship }\end{array}$ & $\begin{array}{l}0.14 \\
(0.35)\end{array}$ \\
\hline Wife's age & Age in years & $\begin{array}{l}45.7 \\
(14.6)\end{array}$ \\
\hline Husband's age & & $\begin{array}{l}48.3 \\
(14.8)\end{array}$ \\
\hline
\end{tabular}


Table A2. Bi-variate probit estimates of propensity to report financial stress Utilities

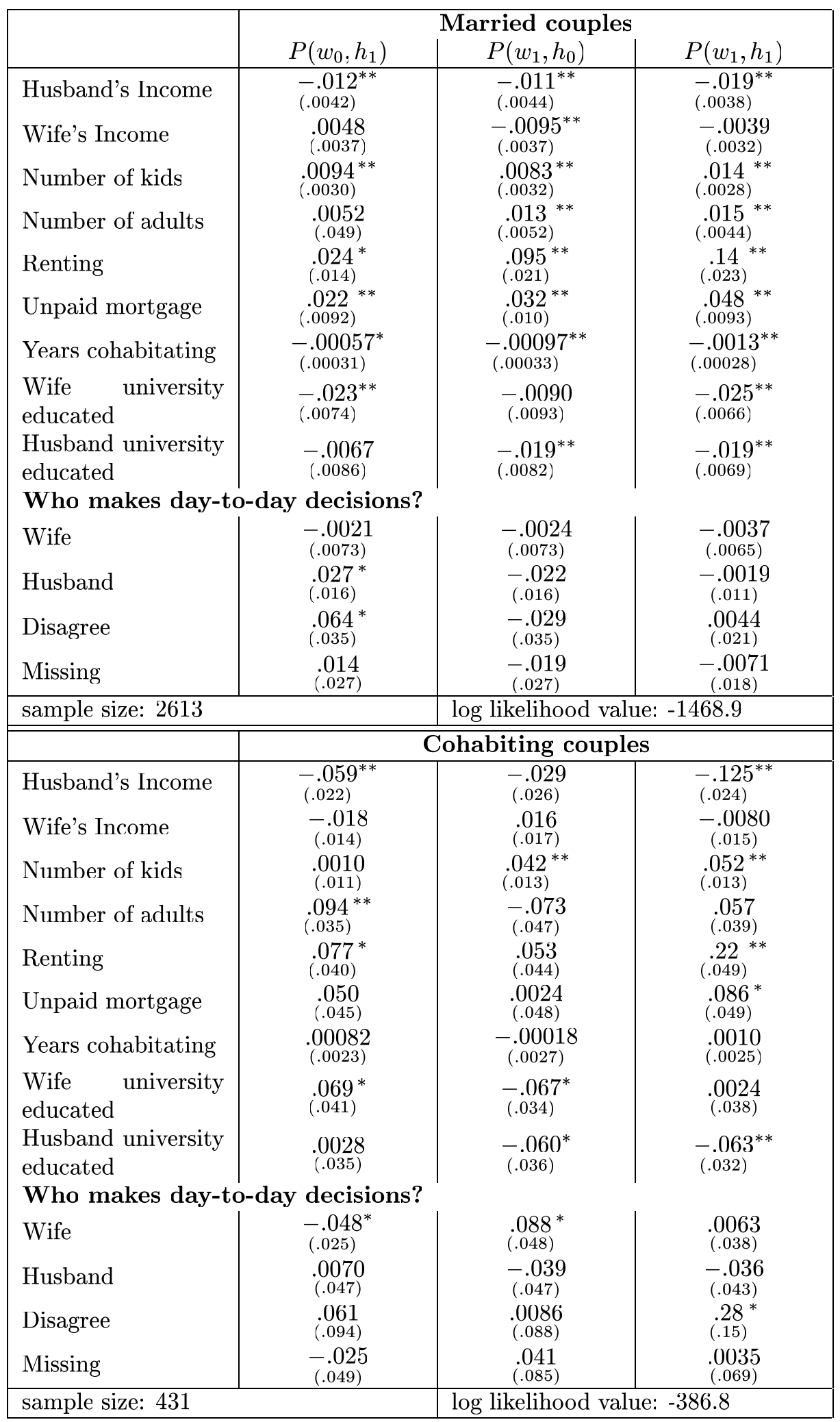


Table A3. Bi-variate probit estimates of propensity to report financial stress Mortgage

\begin{tabular}{|c|c|c|c|}
\hline & \multicolumn{3}{|c|}{ Married couples } \\
\hline & $P\left(w_{0}, h_{1}\right)$ & $P\left(w_{1}, h_{0}\right)$ & $P\left(w_{1}, h_{1}\right)$ \\
\hline Husband's Income & $\begin{array}{l}-.0049 \\
(.0030)\end{array}$ & $\begin{array}{c}-.0025 \\
(.0031)\end{array}$ & $\begin{array}{l}-.0036^{* *} \\
(.0018)\end{array}$ \\
\hline Wife's Income & $\begin{array}{l}.00021 \\
(.0026)\end{array}$ & $\begin{array}{l}-.0058^{* *} \\
(.0025)\end{array}$ & $\begin{array}{l}-.0027^{*} \\
(.0015)\end{array}$ \\
\hline Number of kids & $\begin{array}{l}.0043^{*} \\
(.0022)\end{array}$ & $\begin{array}{l}.0011 \\
(.0023)\end{array}$ & $\begin{array}{l}.0026^{*} \\
(.0014)\end{array}$ \\
\hline Number of adults & $\begin{array}{l}.0053 \\
(.0034)\end{array}$ &.$_{(.0035)}^{.006}{ }^{*}$ & $\begin{array}{l}.0054^{* *} \\
(.0021)\end{array}$ \\
\hline Renting & ${ }^{.042^{* *}}$ & $\begin{array}{l}.056^{* *} \\
(.018)\end{array}$ & ${ }_{(.073)}$ \\
\hline Unpaid mortgage & $\left(_{(.0079)}^{* *}\right.$ & 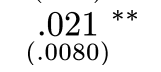 & ${ }^{.023} 3^{* *}$ \\
\hline Years cohabitating & $\begin{array}{l}-.000025 \\
(.00023)\end{array}$ & $\begin{array}{l}-.00042^{*} \\
(.00023)\end{array}$ & $\begin{array}{l}-.00021 \\
(.00013)\end{array}$ \\
\hline $\begin{array}{l}\text { Wife university } \\
\text { educated }\end{array}$ & $\begin{array}{l}-.0058 \\
(.0063)\end{array}$ & $\begin{array}{l}-.015^{* *} \\
(.0056)\end{array}$ & $\begin{array}{l}-.0093^{* *} \\
(.0032)\end{array}$ \\
\hline $\begin{array}{l}\text { Husband university } \\
\text { educated }\end{array}$ & $\begin{array}{l}-.0065 \\
(.0060)\end{array}$ & $\begin{array}{l}-.0054 \\
(.0064)\end{array}$ & $\begin{array}{l}-.0056 \\
(.0035)\end{array}$ \\
\hline \multicolumn{4}{|c|}{ Who makes day-to-day decisions? } \\
\hline Wife & $\begin{array}{l}-.0074 \\
(.0051)\end{array}$ & $\begin{array}{l}.00073 \\
(.0056)\end{array}$ & $\begin{array}{l}-.0034 \\
(.0031)\end{array}$ \\
\hline Husband & $\begin{array}{l}.0085 \\
(.011)\end{array}$ & $\begin{array}{l}-.0044 \\
(.0081)\end{array}$ & $\begin{array}{l}.0015 \\
(.0056)\end{array}$ \\
\hline Disagree & $\begin{array}{l}.024 \\
(.023)\end{array}$ & $\begin{array}{l}.0037 \\
(.016)\end{array}$ & $\begin{array}{l}.014 \\
(.014)\end{array}$ \\
\hline Missing & $\begin{array}{l}.024 \\
(.024) \\
\end{array}$ & $\begin{array}{c}-.0068 \\
(.013)\end{array}$ & $\begin{array}{l}.0053 \\
(.012) \\
\end{array}$ \\
\hline \multicolumn{2}{|l|}{ sample size: 2613} & \multicolumn{2}{|c|}{ log likelihood value: -851.9} \\
\hline & \multicolumn{3}{|c|}{ Cohabiting couples } \\
\hline Husband's Income & $\begin{array}{l}-.037^{* *} \\
(.015)\end{array}$ & $\begin{array}{l}-.024^{*} \\
(.014)\end{array}$ & $\begin{array}{l}-.045^{* *} \\
(.012)\end{array}$ \\
\hline Wife's Income & $\begin{array}{c}-.0068 \\
(.010)\end{array}$ & $\begin{array}{c}-.0072 \\
(.010)\end{array}$ & $\begin{array}{l}-.010 \\
(.0081)\end{array}$ \\
\hline Number of kids & $\begin{array}{l}.012 \\
(.0086)\end{array}$ & $\begin{array}{l}.0097 \\
(.0083)\end{array}$ & ${ }^{.016} 6^{* *}$ \\
\hline Number of adults & $\begin{array}{l}.033 \\
(.029)\end{array}$ & $\begin{array}{l}-.017 \\
(.032)\end{array}$ & $\begin{array}{l}.012 \\
(.023)\end{array}$ \\
\hline Renting & $\begin{array}{l}.061 \\
(.040)\end{array}$ & $i_{(.044)}^{.094^{* *}}$ & $(.041)^{* *}$ \\
\hline Unpaid mortgage & .031 & $\begin{array}{l}.056 \\
(.048)\end{array}$ & $\begin{array}{l}.073^{*} \\
(.039)\end{array}$ \\
\hline Years cohabitating & $\begin{array}{l}-.0020 \\
(.0020)\end{array}$ & $\begin{array}{l}.0017 \\
(.0018)\end{array}$ & $\begin{array}{c}-.00021 \\
(.0015)\end{array}$ \\
\hline $\begin{array}{l}\text { Wife university } \\
\text { educated }\end{array}$ & (.028 & $\begin{array}{l}-.034^{*} \\
(.022)\end{array}$ & $\begin{array}{c}-.011 \\
(.021)\end{array}$ \\
\hline $\begin{array}{l}\text { Husband university } \\
\text { educated }\end{array}$ & $\begin{array}{l}-.013 \\
(.026)\end{array}$ & $\begin{array}{l}.0035 \\
(.030)\end{array}$ & $\begin{array}{c}-.0071 \\
(.021)\end{array}$ \\
\hline \multicolumn{4}{|c|}{ Who makes day-to-day decisions? } \\
\hline Wife & $\begin{array}{c}-.0078 \\
(.025)\end{array}$ & $\begin{array}{l}.019 \\
(.029)\end{array}$ & $\begin{array}{l}.0070 \\
(.022)\end{array}$ \\
\hline Husband & $\begin{array}{l}-.011 \\
(.034)\end{array}$ & $\begin{array}{l}-.040^{*} \\
(.022)\end{array}$ & $\begin{array}{l}-.034^{*} \\
(.018)\end{array}$ \\
\hline Disagree & $\begin{array}{l}.051 \\
(.080)\end{array}$ & $\begin{array}{l}.023 \\
(.066)\end{array}$ & $\begin{array}{l}.073 \\
(.082)\end{array}$ \\
\hline Missing & $\begin{array}{l}.081 \\
(.081)\end{array}$ & $\begin{array}{l}.041 \\
(.051)\end{array}$ & $\begin{array}{r}.084 \\
(.071)\end{array}$ \\
\hline \multicolumn{2}{|l|}{ sample size: 431} & \multicolumn{2}{|c|}{ log likelihood value: -275.1} \\
\hline
\end{tabular}


Table A4. Bi-variate probit estimates of propensity to report financial stress Pawn

\begin{tabular}{|c|c|c|c|}
\hline & \multicolumn{3}{|c|}{ Married couples } \\
\hline & $P\left(w_{0}, h_{1}\right)$ & $P\left(w_{1}, h_{0}\right)$ & $P\left(w_{1}, h_{1}\right)$ \\
\hline Husband's Income & $\begin{array}{l}-.0034 \\
(.0028)\end{array}$ & $\begin{array}{l}-.0069^{* *} \\
(.0020)\end{array}$ & $\begin{array}{l}-.0041^{* *} \\
(.0012)\end{array}$ \\
\hline Wife's Income & $\begin{array}{c}-.00078 \\
(.0024)\end{array}$ & $\begin{array}{l}-.0049^{* *} \\
(.0017)\end{array}$ & $\begin{array}{l}-.0024^{* *} \\
(.00098)\end{array}$ \\
\hline Number of kids & $\begin{array}{l}.0029 \\
(.0021)\end{array}$ & $\begin{array}{l}.0037^{* *} \\
(.0016)\end{array}$ & $\underbrace{.0026} 6^{* *}$ \\
\hline Number of adults & $\begin{array}{l}-.0030 \\
(.039)\end{array}$ & .0043 & .0010 \\
\hline Renting & $\begin{array}{l}.0056 \\
(.0089)\end{array}$ & $\frac{.018^{*}}{(.010)}$ & $\left.{ }_{(.0056)}^{.010}\right)^{*}$ \\
\hline Unpaid mortgage & $\begin{array}{l}.0019 \\
(.0059)\end{array}$ & $\begin{array}{l}.0076 \\
(.0051)\end{array}$ & $\begin{array}{l}.0040 \\
(.0027)\end{array}$ \\
\hline Years cohabitating & $\begin{array}{l}-.00026 \\
(.00021)\end{array}$ & $\begin{array}{l}-.00026 \\
(.00017)\end{array}$ & $\begin{array}{l}-.00020^{* *} \\
(.00009)\end{array}$ \\
\hline $\begin{array}{l}\text { Wife university } \\
\text { educated }\end{array}$ & $\frac{-.0066^{* *}}{(.0054)}$ & $\begin{array}{c}.0014 \\
(.0053)\end{array}$ & $\begin{array}{c}-.0015 \\
(.0024)\end{array}$ \\
\hline $\begin{array}{l}\text { Husband university } \\
\text { educated }\end{array}$ & $\begin{array}{l}.0071 \\
(.0072)\end{array}$ & $\begin{array}{l}-.0040 \\
(.0043)\end{array}$ & $\begin{array}{l}.000012 \\
(.0026)\end{array}$ \\
\hline \multicolumn{4}{|c|}{ Who makes day-to-day decisions? } \\
\hline Disagree or missing & $\begin{array}{l}.029 \\
(.018) \\
\end{array}$ & $\begin{array}{c}-.0041 \\
(.0058)\end{array}$ & $\begin{array}{l}.0042 \\
(.0060)\end{array}$ \\
\hline \multicolumn{2}{|l|}{ sample size: 2613} & \multicolumn{2}{|c|}{ log likelihood value: -575.8} \\
\hline & \multicolumn{3}{|c|}{ Cohabiting couples } \\
\hline Husband's Income & $\begin{array}{l}-.024^{*} \\
(.013)\end{array}$ & $\begin{array}{c}-.030 \\
(.012)\end{array}$ & $\begin{array}{l}-.024^{* *} \\
(.0080)\end{array}$ \\
\hline Wife's Income & $\begin{array}{l}.0014 \\
(.010)\end{array}$ & $\begin{array}{l}.0037 \\
(.0079)\end{array}$ & $\begin{array}{l}-.0013 \\
(.0047)\end{array}$ \\
\hline Number of kids & $\begin{array}{l}-.0025 \\
(.0082)\end{array}$ & $\begin{array}{l}.0098 \\
(.0063)\end{array}$ & $\begin{array}{l}.0040 \\
(.0039)\end{array}$ \\
\hline Number of adults & $\begin{array}{l}.013 \\
(.026)\end{array}$ & $\begin{array}{l}.020 \\
(.019)\end{array}$ & $\begin{array}{l}.014 \\
(.012)\end{array}$ \\
\hline Renting & $\begin{array}{l}.0098 \\
(.028)\end{array}$ & $\begin{array}{l}.079^{*} \\
(.044)\end{array}$ & ${ }_{(.022)}^{.043^{* *}}$ \\
\hline Unpaid mortgage & $\begin{array}{l}-.017 \\
(.027)\end{array}$ & .077 & $\begin{array}{l}.026 \\
(.021)\end{array}$ \\
\hline Years cohabitating & $\begin{array}{l}.00068 \\
(.0016)\end{array}$ & $\begin{array}{c}-.00016 \\
(.0014)\end{array}$ & $\begin{array}{l}.00018 \\
(.00076)\end{array}$ \\
\hline $\begin{array}{l}\text { Wife university } \\
\text { educated }\end{array}$ & $\begin{array}{l}-.030 \\
(.021)\end{array}$ & $\begin{array}{l}-.0092^{*} \\
(.020)\end{array}$ & $\begin{array}{l}-.015 \\
(.010)\end{array}$ \\
\hline $\begin{array}{l}\text { Husband university } \\
\text { educated }\end{array}$ & $\begin{array}{l}-.012 \\
(.025)\end{array}$ & $\begin{array}{l}-.0022^{*} \\
(.022)\end{array}$ & $\begin{array}{c}-.0057 \\
(.012)\end{array}$ \\
\hline \multicolumn{4}{|c|}{ Who makes day-to-day decisions? } \\
\hline Disagree or missing & $\begin{array}{l}.078 \\
(.058) \\
\end{array}$ & $\begin{array}{r}.029 \\
(.039) \\
\end{array}$ & $\begin{array}{l}.066 \\
(.043)\end{array}$ \\
\hline \multicolumn{2}{|l|}{ sample size: 431} & \multicolumn{2}{|c|}{ log likelihood value: -200.9} \\
\hline
\end{tabular}


Table A5. Bi-variate probit estimates of propensity to report financial stress Friends

\begin{tabular}{|c|c|c|c|}
\hline & \multicolumn{3}{|c|}{ Married couples } \\
\hline & $P\left(w_{0}, h_{1}\right)$ & $P\left(w_{1}, h_{0}\right)$ & $P\left(w_{1}, h_{1}\right)$ \\
\hline Husband's Income & $\begin{array}{c}-.0062^{*} \\
(.0033)\end{array}$ & $\begin{array}{l}-.011^{* *} \\
(.0028)\end{array}$ & $\begin{array}{l}-.012^{* *} \\
(.0025)\end{array}$ \\
\hline Wife's Income & $\begin{array}{l}-.0033 \\
(.0028)\end{array}$ & $\begin{array}{l}-.0027 \\
(.0024)\end{array}$ & $\begin{array}{l}-.0041^{* *} \\
(.0021)\end{array}$ \\
\hline Number of kids & $\begin{array}{l}.0049^{* *} \\
(.0024)\end{array}$ & $\begin{array}{l}.0045^{* *} \\
(.0020)\end{array}$ & ${ }_{\left(.0064^{* *}\right.}^{.0018)}$ \\
\hline Number of adults & -.00014 & $\begin{array}{l}.0068^{*} \\
(.0035)\end{array}$ & ${ }_{(.0051)}$ \\
\hline Renting & ${ }_{\left(.032^{* *}\right.}$ & $\begin{array}{l}.048^{* *} \\
(.016)\end{array}$ & $\begin{array}{l}.078^{* *} \\
(.017)\end{array}$ \\
\hline Unpaid mortgage &.$_{(.018}{ }^{* *}$ &.$_{(.0070)}^{.014}{ }^{* *}$ &.$_{(.0064)}^{.023}$ \\
\hline Years cohabitating & $\begin{array}{l}-.00084^{* *} \\
(.00026)\end{array}$ & $\begin{array}{l}-.00088^{* *} \\
(.00023)\end{array}$ & $\begin{array}{l}-.0012^{* *} \\
(.00020)\end{array}$ \\
\hline $\begin{array}{l}\text { Wife university } \\
\text { educated }\end{array}$ & $\begin{array}{l}-.016^{* *} \\
(.0059)\end{array}$ & .0047 & -.0075 \\
\hline $\begin{array}{l}\text { Husband university } \\
\text { educated }\end{array}$ & $\begin{array}{l}-.016^{* *} \\
(.0056)\end{array}$ & $\begin{array}{l}-.0017 \\
(.0060)\end{array}$ & $\begin{array}{l}-.011^{* *} \\
(.0044)\end{array}$ \\
\hline \multicolumn{4}{|c|}{ Who makes day-to-day decisions? } \\
\hline Wife & $\begin{array}{l}-.011^{*} \\
(.0056)\end{array}$ & $\begin{array}{l}.0033 \\
(.0055)\end{array}$ & $\begin{array}{l}-.0043 \\
(.0043)\end{array}$ \\
\hline Husband & $\begin{array}{l}.0055 \\
(.011)\end{array}$ & $\begin{array}{l}.0031 \\
. .0089)\end{array}$ & .0060 \\
\hline Disagree & $\begin{array}{l}.0064 \\
(.018)\end{array}$ & .014 & .016 \\
\hline Missing & $\begin{array}{l}.029 \\
(.026) \\
\end{array}$ & $\begin{array}{r}.0088 \\
(.018) \\
\end{array}$ & $\begin{array}{r}.028 \\
(.022) \\
\end{array}$ \\
\hline \multicolumn{2}{|l|}{ sample size: 2613} & \multicolumn{2}{|c|}{ log likelihood value: -1029.8} \\
\hline & \multicolumn{3}{|c|}{ Cohabiting couples } \\
\hline Husband's Income & $\begin{array}{l}-.041^{* *} \\
(.017)\end{array}$ & $\begin{array}{c}-.012 \\
(.023)\end{array}$ & $\begin{array}{l}-.056^{* *} \\
(.017)\end{array}$ \\
\hline Wife's Income & $\begin{array}{l}-.014 \\
(.012)\end{array}$ & $\begin{array}{l}.0019 \\
(.017)\end{array}$ & $\begin{array}{l}-.014 \\
(.012)\end{array}$ \\
\hline Number of kids & $\begin{array}{c}-.0020 \\
(.010)\end{array}$ & )$_{(.014)^{* *}}$ & $\begin{array}{l}.022^{* *} \\
(.010\end{array}$ \\
\hline Number of adults & $\begin{array}{l}.053 \\
(.034)\end{array}$ & $\begin{array}{l}-.097^{*} \\
(.055)\end{array}$ & $\begin{array}{l}-.015 \\
(.034)\end{array}$ \\
\hline Renting & $\begin{array}{l}.048 \\
(.035)\end{array}$ & $\left(.12^{* *}\right.$ & ${ }_{(.042)}^{.18^{* *}}$ \\
\hline Unpaid mortgage & $\begin{array}{c}-.0041 \\
(.039)\end{array}$ & $\begin{array}{l}.065 \\
(.056)\end{array}$ & $\begin{array}{l}.047 \\
(.040)\end{array}$ \\
\hline Years cohabitating & $\begin{array}{l}-.0034 \\
(.0024)\end{array}$ & $\frac{-.0035}{(.0031)}$ & $\frac{-.0065^{* *}}{(.0022)}$ \\
\hline $\begin{array}{l}\text { Wife university } \\
\text { educated }\end{array}$ & (.018 & $\begin{array}{l}.013 \\
(.042)\end{array}$ & $\begin{array}{l}.033 \\
(.034)\end{array}$ \\
\hline $\begin{array}{l}\text { Husband university } \\
\text { educated }\end{array}$ & $\begin{array}{l}-.046^{*} \\
(.025)\end{array}$ & $\begin{array}{l}-.026 \\
(.039)\end{array}$ & $\begin{array}{l}-.063^{* *} \\
(.023)\end{array}$ \\
\hline \multicolumn{4}{|c|}{ Who makes day-to-day decisions? } \\
\hline Wife & $\begin{array}{c}-.0080 \\
(.029)\end{array}$ & $\begin{array}{l}.098^{*} \\
(.052)\end{array}$ & $\begin{array}{l}.074^{*} \\
(.041)\end{array}$ \\
\hline Husband & .018 & $\begin{array}{c}-.0047 \\
(.057)\end{array}$ & $\begin{array}{l}.016 \\
(.045)\end{array}$ \\
\hline Disagree & $\begin{array}{l}-.029 \\
(.049)\end{array}$ & .18 & $\begin{array}{l}.12 \\
(.12)\end{array}$ \\
\hline Missing & $\begin{array}{l}.040 \\
(.068)\end{array}$ & $\begin{array}{r}.018 \\
(.077) \\
\end{array}$ & $\begin{array}{r}.076 \\
(.077)\end{array}$ \\
\hline \multicolumn{2}{|l|}{ sample size: 431} & \multicolumn{2}{|c|}{ log likelihood value: -386.3} \\
\hline
\end{tabular}


Table A6. Bi-variate probit estimates of propensity to report financial stress Welfare

\begin{tabular}{|c|c|c|c|}
\hline & \multicolumn{3}{|c|}{ Married couples } \\
\hline & $P\left(w_{0}, h_{1}\right)$ & $P\left(w_{1}, h_{0}\right)$ & $P\left(w_{1}, h_{1}\right)$ \\
\hline Husband's Income & $\begin{array}{l}-.0028^{* *} \\
(.0013)\end{array}$ & $\begin{array}{l}-.0039^{* *} \\
(.0014)\end{array}$ & $\begin{array}{l}-.0022^{* *} \\
(.00078)\end{array}$ \\
\hline Wife's Income & $\begin{array}{l}-.0017 \\
(.0012)\end{array}$ & $\begin{array}{l}-.0016 \\
(.0013)\end{array}$ & $\begin{array}{l}-.0011^{*} \\
(.00057)\end{array}$ \\
\hline Number of kids & $\begin{array}{c}-.000047 \\
(.0011)\end{array}$ & $\begin{array}{l}.00066 \\
(.0012)\end{array}$ & $\begin{array}{l}.00019 \\
(.00051)\end{array}$ \\
\hline Number of adults & $\begin{array}{l}-.0018 \\
(.020)\end{array}$ & $\begin{array}{l}.0045^{* *} \\
(.0018)\end{array}$ & $\begin{array}{l}.00076 \\
(.00083)\end{array}$ \\
\hline Renting & ${ }_{(.030)}^{.03 *}$ & $\begin{array}{l}.012 \\
(.0080)\end{array}$ & $\left(_{(.0072)}^{.018}{ }^{* *}\right.$ \\
\hline Unpaid mortgage & $\left(_{(.0051)}{ }^{* *}\right.$ & $\begin{array}{l}-.0028 \\
(.0033)\end{array}$ & .0024 \\
\hline Years cohabitating & $\begin{array}{l}.000022 \\
(.0001)\end{array}$ & $\begin{array}{l}-.00016 \\
(.00011)\end{array}$ & $\begin{array}{c}-.000043 \\
(.00005)\end{array}$ \\
\hline $\begin{array}{l}\text { Wife university } \\
\text { educated }\end{array}$ & .0017 & $\begin{array}{l}-.0049 \\
(.0030)\end{array}$ & $\begin{array}{c}-.0012 \\
(.0014)\end{array}$ \\
\hline $\begin{array}{l}\text { Husband university } \\
\text { educated }\end{array}$ & $\begin{array}{c}-.00040 \\
(.0034)\end{array}$ & $\begin{array}{l}.00098^{* *} \\
(.0042)\end{array}$ & $\begin{array}{l}.00016 \\
(.0016)\end{array}$ \\
\hline \multicolumn{4}{|c|}{ Who makes day-to-day decisions? } \\
\hline Disagree or missing &.$_{(.016)}^{* *}$ & $\begin{array}{c}-.0028 \\
(.0040)\end{array}$ & $\begin{array}{l}.0050 \\
(.0051) \\
\end{array}$ \\
\hline \multicolumn{2}{|l|}{ sample size: 2613} & \multicolumn{2}{|c|}{ log likelihood value: -329.0} \\
\hline & \multicolumn{3}{|c|}{ Cohabiting couples } \\
\hline
\end{tabular}


Table A7. Bi-variate probit estimates of propensity to report financial stress At least one financial difficulty

\begin{tabular}{|c|c|c|c|}
\hline & \multicolumn{3}{|c|}{ Married couples } \\
\hline & $P\left(w_{0}, h_{1}\right)$ & $P\left(w_{1}, h_{0}\right)$ & $P\left(w_{1}, h_{1}\right)$ \\
\hline Husband's Income & $\begin{array}{l}-.018^{* *} \\
(.0050)\end{array}$ & $\begin{array}{l}-.014^{* *} \\
(.0052)\end{array}$ & $\begin{array}{l}-.031^{* *} \\
(.0049)\end{array}$ \\
\hline Wife's Income & $\begin{array}{l}.000031 \\
(.0041)\end{array}$ & $\begin{array}{l}-.012^{* *} \\
(.0043)\end{array}$ & $\begin{array}{l}-.011^{* *} \\
(.0040)\end{array}$ \\
\hline Number of kids & $\begin{array}{l}.0084^{* *} \\
(.0037)\end{array}$ & $\begin{array}{l}.0096^{* *} \\
(.0039)\end{array}$ &.$_{(.0037)}^{.018^{* *}}$ \\
\hline Number of adults & .0020 & $\left(_{(.0061)}^{.018^{* *}}\right.$ & $\left(_{(.0057)}^{.020}\right)^{* *}$ \\
\hline Renting & $\begin{array}{l}.030^{*} \\
(.016)\end{array}$ & $i_{(.021)}^{.084^{* *}}$ &.$^{.18} 8^{* *}$ \\
\hline Unpaid mortgage &.$_{(.011)}^{.024^{* *}}$ & $\begin{array}{l}.032^{* *} \\
(.011)\end{array}$ &.$_{(.011)}^{059^{* *}}$ \\
\hline Years cohabitating & $\begin{array}{l}-.0011^{* *} \\
(.00037)\end{array}$ & $\begin{array}{l}-.0016^{* *} \\
(.00039)\end{array}$ & $\begin{array}{l}-.0026^{* *} \\
(.00036)\end{array}$ \\
\hline $\begin{array}{l}\text { Wife university } \\
\text { educated }\end{array}$ & $\begin{array}{l}-.025^{* *} \\
(.0093)\end{array}$ & -.011 & $\begin{array}{l}-.033^{* *} \\
(.0087)\end{array}$ \\
\hline $\begin{array}{l}\text { Husband university } \\
\text { educated }\end{array}$ & $\frac{-.010}{(.010)}$ & $\frac{-.010}{(.011)}$ & $\begin{array}{l}-.019^{* *} \\
(.0093)\end{array}$ \\
\hline \multicolumn{4}{|c|}{ Who makes day-to-day decisions? } \\
\hline Wife & $\begin{array}{l}-.012 \\
(.0085)\end{array}$ & .0050 & $\begin{array}{l}-.0079 \\
(.0084)\end{array}$ \\
\hline Husband & ${ }_{(.019)}^{.047^{* *}}$ & $\begin{array}{l}-.036^{* *} \\
(.010)\end{array}$ & $\begin{array}{l}-.0038 \\
(.014)\end{array}$ \\
\hline Disagree & .017 & $\begin{array}{l}.011 \\
(.028)\end{array}$ & .032 \\
\hline Missing & $\begin{array}{l}.047 \\
(.035) \\
\end{array}$ & $\begin{array}{l}-.018 \\
(.022)\end{array}$ & $\begin{array}{l}.021 \\
(.030)\end{array}$ \\
\hline \multicolumn{2}{|l|}{ sample size: 2613} & \multicolumn{2}{|c|}{ log likelihood value: -1841.8} \\
\hline & \multicolumn{3}{|c|}{ Cohabiting couples } \\
\hline Husband's Income & $\begin{array}{l}-.061^{* *} \\
(.024)\end{array}$ & $\begin{array}{l}.0085 \\
(.029)\end{array}$ & $\begin{array}{l}-.185^{* *} \\
(.033)\end{array}$ \\
\hline Wife's Income & $\begin{array}{c}-.0031 \\
(.014)\end{array}$ & $\begin{array}{c}-.00047 \\
(.018)\end{array}$ & $\begin{array}{l}-.012 \\
(.020)\end{array}$ \\
\hline Number of kids & $\begin{array}{l}-.0095 \\
(.012)\end{array}$ & ${ }_{(.015)}$ & $i^{.061}{ }^{* *}$ \\
\hline Number of adults & $i^{.082^{* *}}$ & $\begin{array}{l}-.084^{*} \\
(.050)\end{array}$ & $\begin{array}{l}.061 \\
(.052)\end{array}$ \\
\hline Renting & $\begin{array}{l}.0086 \\
(.035)\end{array}$ & $\begin{array}{l}.072 \\
(.046)\end{array}$ &.$_{(.055)}^{* *}$ \\
\hline Unpaid mortgage & .017 & $\begin{array}{l}.0053 \\
(.049)\end{array}$ & $\begin{array}{l}.076 \\
(.057)\end{array}$ \\
\hline Years cohabitating & $\begin{array}{l}-.00064 \\
(.0024)\end{array}$ & $\begin{array}{l}-.00039 \\
(.0030)\end{array}$ & $\begin{array}{l}-.0032 \\
(.0033)\end{array}$ \\
\hline $\begin{array}{l}\text { Wife university } \\
\text { educated }\end{array}$ & $\begin{array}{l}.0015 \\
(.035)\end{array}$ & -.017 & $\begin{array}{l}-.036 \\
(.048)\end{array}$ \\
\hline $\begin{array}{l}\text { Husband university } \\
\text { educated }\end{array}$ & $\begin{array}{l}-.026 \\
(.033)\end{array}$ & $\begin{array}{l}.0091 \\
(.046)\end{array}$ & $\begin{array}{l}-.058 \\
(.047)\end{array}$ \\
\hline \multicolumn{4}{|c|}{ Who makes day-to-day decisions? } \\
\hline Wife & $\begin{array}{l}-.048^{*} \\
(.028)\end{array}$ & $\begin{array}{l}.099^{*} \\
(.052)\end{array}$ & $\begin{array}{l}.065 \\
(.055)\end{array}$ \\
\hline Husband & $\begin{array}{l}.0059^{* *} \\
(.049)\end{array}$ & $\begin{array}{l}-.030 \\
(.055)\end{array}$ & $\begin{array}{c}-.050 \\
(.061)\end{array}$ \\
\hline Disagree & $\begin{array}{c}-.014 \\
(.076)\end{array}$ & $\begin{array}{l}.031 \\
(.11)\end{array}$ & $\begin{array}{l}.26 \\
(.16)\end{array}$ \\
\hline Missing & $\begin{array}{l}-.016 \\
(.061)\end{array}$ & $\begin{array}{l}.034 \\
(.094) \\
\end{array}$ & $\begin{array}{l}.029 \\
(.10)\end{array}$ \\
\hline \multicolumn{2}{|l|}{ sample size: 431} & \multicolumn{2}{|c|}{ log likelihood value: -437.9} \\
\hline
\end{tabular}


Table A8. Bi-variate probit estimates of propensity to report financial stress Two or more reports of financial difficulty

\begin{tabular}{|c|c|c|c|}
\hline & \multicolumn{3}{|c|}{ Married couples } \\
\hline & $P\left(w_{0}, h_{1}\right)$ & $P\left(w_{1}, h_{0}\right)$ & $P\left(w_{1}, h_{1}\right)$ \\
\hline Husband's Income & $\begin{array}{c}-.0053 \\
(.0035)\end{array}$ & $\begin{array}{l}-.011^{* *} \\
(.0034)\end{array}$ & $\begin{array}{l}-.011^{* *} \\
(.0027)\end{array}$ \\
\hline Wife's Income & $\begin{array}{l}.00046 \\
(.0030)\end{array}$ & $\begin{array}{l}-.0073^{* *} \\
(.0029)\end{array}$ & $\begin{array}{l}-.0043^{* *} \\
(.0022)\end{array}$ \\
\hline Number of kids & $\begin{array}{l}.0075^{* *} \\
(.0025)\end{array}$ & $\begin{array}{l}.0045^{*} \\
(.0026)\end{array}$ & $\begin{array}{l}.0078^{* *} \\
(.0020)\end{array}$ \\
\hline Number of adults & .0066 & $\begin{array}{l}.0055 \\
(.0043)\end{array}$ & $\begin{array}{l}.0079^{* *} \\
(.0031)\end{array}$ \\
\hline Renting & ${ }_{(.0517)}^{* *}$ & $\begin{array}{l}.062^{* *} \\
(.018)\end{array}$ & $\left(.12^{* *}\right.$ \\
\hline Unpaid mortgage & ${ }^{.028}(.0087)^{* *}$ & $\left(_{(.02084)}^{* *}\right.$ & $\left(_{(.0073)}\right)^{* *}$ \\
\hline Years cohabitating & $\begin{array}{l}-.00035 \\
(.00026)\end{array}$ & $\begin{array}{l}-.00074^{* *} \\
(.00027)\end{array}$ & $\begin{array}{l}-.00070^{* *} \\
(.00020)\end{array}$ \\
\hline $\begin{array}{l}\text { Wife university } \\
\text { educated }\end{array}$ & $\begin{array}{l}-.016^{* *} \\
(.0062)\end{array}$ & $\begin{array}{l}-.0052 \\
(.0075)\end{array}$ & $\begin{array}{l}-.014^{* *} \\
(.0048)\end{array}$ \\
\hline $\begin{array}{l}\text { Husband university } \\
\text { educated }\end{array}$ & $\begin{array}{l}-.011^{*} \\
(.0067)\end{array}$ & $\begin{array}{l}-.012^{*} \\
(.0067)\end{array}$ & $\begin{array}{l}-.014^{* *} \\
(.0047)\end{array}$ \\
\hline \multicolumn{4}{|c|}{ Who makes day-to-day decisions? } \\
\hline Wife & $\begin{array}{l}-.0049 \\
(.0060)\end{array}$ & $\begin{array}{l}-.0031 \\
(.0062)\end{array}$ & $\begin{array}{l}-.0051 \\
(.0045)\end{array}$ \\
\hline Husband & $\begin{array}{l}-.00043 \\
(.010)\end{array}$ & $\begin{array}{l}-.0015 \\
(.010)\end{array}$ & $\begin{array}{l}-.0012 \\
(.0075)\end{array}$ \\
\hline Disagree & .050 & $\begin{array}{l}-.015 \\
(.011)\end{array}$ & .010 \\
\hline Missing & $\begin{array}{l}.041 \\
(.031) \\
\end{array}$ & $\begin{array}{c}-.013 \\
(.013) \\
\end{array}$ & $\begin{array}{c}.00912 \\
(.018)\end{array}$ \\
\hline \multicolumn{2}{|l|}{ sample size: 2613} & \multicolumn{2}{|c|}{ log likelihood value: -1117.0} \\
\hline & \multicolumn{3}{|c|}{ Cohabiting couples } \\
\hline Husband's Income & $\begin{array}{l}-.047^{* *} \\
(.019)\end{array}$ & $\begin{array}{l}-.049^{* *} \\
(.025)\end{array}$ & $\begin{array}{l}-.097^{* *} \\
(.020)\end{array}$ \\
\hline Wife's Income & $\begin{array}{l}-.021^{*} \\
(.013)\end{array}$ & $\begin{array}{l}.016 \\
(.017)\end{array}$ & $\begin{array}{l}-.010 \\
(.012)\end{array}$ \\
\hline Number of kids & $\begin{array}{l}.0069 \\
(.011)\end{array}$ & $i^{.031} 1^{* *}$ & ${ }^{.035^{* *}}$ \\
\hline Number of adults & $\begin{array}{l}.059^{*} \\
(.035)\end{array}$ & $\begin{array}{l}-.065 \\
(.050)\end{array}$ & $\begin{array}{l}.013 \\
(.035)\end{array}$ \\
\hline Renting & $\begin{array}{l}.048 \\
(.037)\end{array}$ & $(.050)^{* *}$ &.$_{(.047)^{* *}}$ \\
\hline Unpaid mortgage & .011 & $\begin{array}{l}.083 \\
(.058)\end{array}$ & $\begin{array}{l}.093^{*} \\
(.046)\end{array}$ \\
\hline Years cohabitating & $\begin{array}{l}-.0043^{*} \\
(.0024)\end{array}$ & $\begin{array}{l}.0028 \\
(.0028)\end{array}$ & $\begin{array}{l}-.0026 \\
(.0022)\end{array}$ \\
\hline $\begin{array}{l}\text { Wife university } \\
\text { educated }\end{array}$ & $\begin{array}{l}.055 \\
(.039)\end{array}$ & -.052 & $\begin{array}{l}.0070 \\
(.032)\end{array}$ \\
\hline $\begin{array}{l}\text { Husband university } \\
\text { educated }\end{array}$ & $\begin{array}{l}-.012 \\
(.031)\end{array}$ & $\frac{-.061^{*}}{(.035)}$ & $\begin{array}{l}-.059^{* *} \\
(.025)\end{array}$ \\
\hline \multicolumn{4}{|c|}{ Who makes day-to-day decisions? } \\
\hline Wife & $\begin{array}{l}-.015 \\
(.029)\end{array}$ & $\begin{array}{l}.062 \\
(.047)\end{array}$ & $\begin{array}{l}.034^{*} \\
(.036)\end{array}$ \\
\hline Husband & $\begin{array}{l}-.042 \\
(.031)\end{array}$ & $\begin{array}{l}.042 \\
(.066)\end{array}$ & $\begin{array}{l}-.025 \\
(.038)\end{array}$ \\
\hline Disagree & $\begin{array}{l}.064 \\
(.10)\end{array}$ & $\begin{array}{l}.034 \\
(.10)\end{array}$ & $\begin{array}{l}.31^{* *} \\
(.16)\end{array}$ \\
\hline Missing & $\begin{array}{l}.0019 \\
(.057) \\
\end{array}$ & $\begin{array}{r}.070 \\
(.093) \\
\end{array}$ & $\begin{array}{r}.079 \\
(.083) \\
\end{array}$ \\
\hline \multicolumn{2}{|l|}{ sample size: 431} & \multicolumn{2}{|c|}{ log likelihood value: -356.8} \\
\hline
\end{tabular}




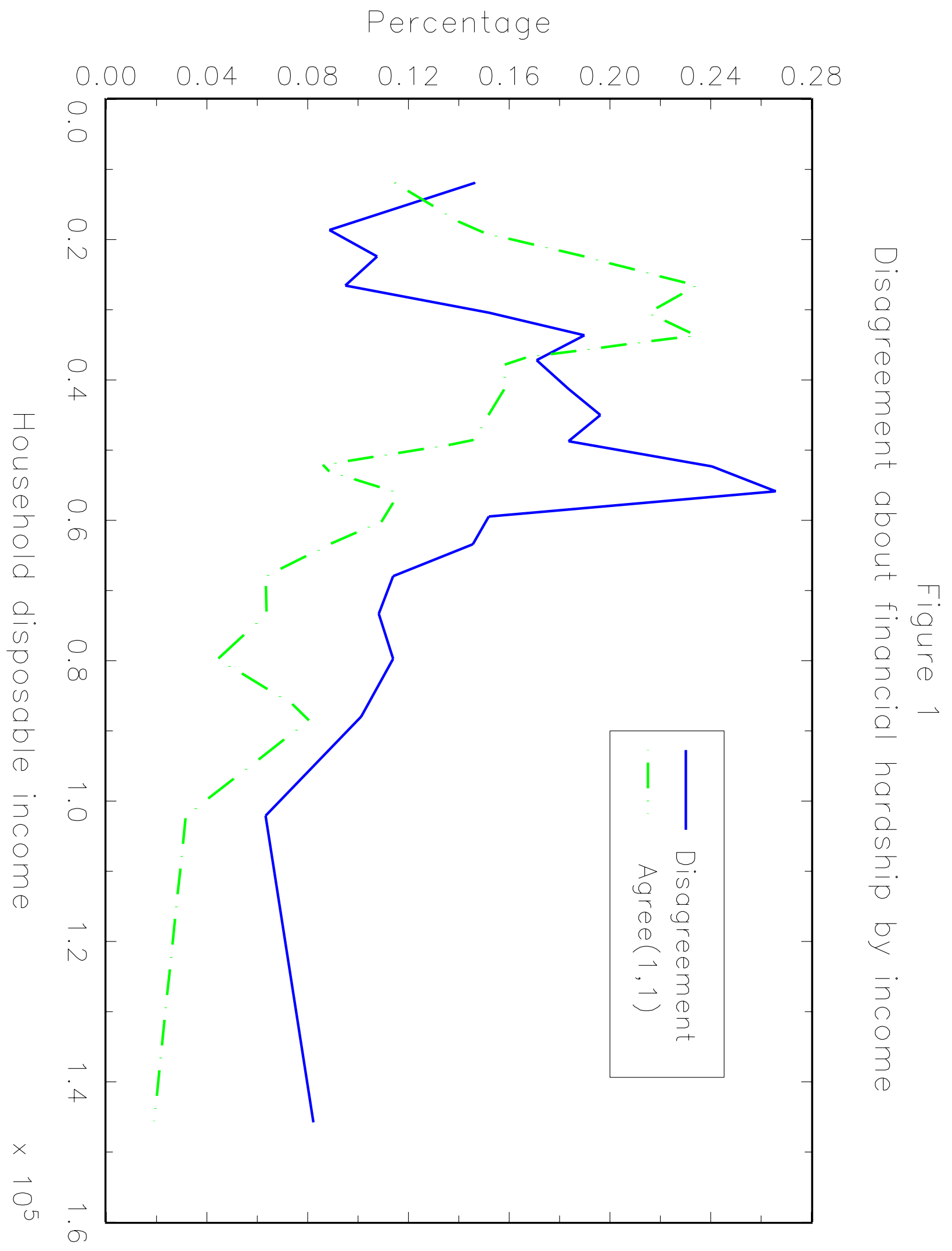

